$9-8-2020$

\title{
Capitalizing on Healthy Lawyers: The Business Case for Law Firms to Promote and Prioritize Lawyer Well-Being
}

Jarrod F. Reich

Follow this and additional works at: https://digitalcommons.law.villanova.edu/vlr

Part of the Law and Psychology Commons, Legal Ethics and Professional Responsibility Commons, and the Legal Profession Commons

\section{Recommended Citation}

Jarrod F. Reich, Capitalizing on Healthy Lawyers: The Business Case for Law Firms to Promote and Prioritize Lawyer Well-Being, 65 Vill. L. Rev. 361 (2020).

Available at: https://digitalcommons.law.villanova.edu/vlr/vol65/iss2/3

This Article is brought to you for free and open access by Villanova University Charles Widger School of Law Digital Repository. It has been accepted for inclusion in Villanova Law Review by an authorized editor of Villanova University Charles Widger School of Law Digital Repository. 
CAPITALIZING ON HEALTHY LAWYERS: THE BUSINESS CASE FOR LAW FIRMS TO PROMOTE AND PRIORITIZE LAWYER WELL-BEING

\author{
JARROD F. REICH*
}

This Article is the first to make the business case for firms to promote and prioritize lawyer well-being. For more than three decades, quantitative research has demonstrated that lawyers suffer from depression, anxiety, and addiction far in excess of the general population. Since that time, there have been many calls within and outside the profession for changes to be made to promote, prioritize, and improve lawyer well-being, particularly because many aspects of the current law school and law firm models exacerbate mental health and addiction issues, as well as overall law student and lawyer distress. These calls for change, made on moral and humanitarian grounds, largely have been ignored; in fact, over the years the pervasiveness of mental health and addiction issues within the profession have persisted, if not increased. This Article argues that these moral- and humanitarian-based calls for change have gone unheeded because law firms have not had financial incentives to respond to them.

In making the business case for change, this Article argues that systemic changes designed to support and resources to lawyers will avoid costs associated with lawyer mental health and addiction issues and, more importantly, create efficiencies that will increase firms' long-term financial stability and growth. It demonstrates that this business case is especially strong now in light of not only societal and generational factors, but also changes within the profession itself well. As firms have begun to take incremental steps to promote lawyer well-being, lasting and meaningful change will further benefit firms' collective bottom lines as it will improve: (1) performance, as clients are demanding efficiency in the way their matters are staffed and billed; (2) retention, as that creates efficiencies and the continuous relationships demanded by clients; and (3) recruitment, particularly as younger millennial and Generation Z lawyers-who prioritize mental health and well-being-enter the profession.

* Professor of Legal Writing and Lecturer in Law, University of Miami School of Law. Former associate and counsel, Boies Schiller Flexner LLP. The author is grateful to Steve Armstrong, Sonya Bonneau, Dan Bowling, Bree Buchanan, Danielle Gilson, Meghan Holtzman, David Jaffe, Larry Krieger, Patrick Krill, Todd Peterson, Jeffrey Shulman, and Tim Terrell for their insightful comments on this Article. The author additionally thanks Oliver Armas (Hogan Lovells), Sally King (Akin Gump Strauss Hauer \& Feld LLP), and Wendy Cartland and Linda Myers (Kirkland \& Ellis LLP) for discussing the innovative work their respective firms have begun to undertake to promote the well-being of their employees. Special thanks also to Sara Ellis and Jeremy McCabe for their excellent research assistance and to the Georgetown University Law Center for the grants and administrative support that made this Article possible. 
I. Mental Illness and Addiction in the Legal Profession:

An Empirical Overview ........................ 367

II. Why This Happens: Professional Risk Factors Affecting Mental Health and Addiction ....................... 374

A. "Lawyer Personality" .......................... 375

B. Law School .................................... 378

C. Law Practice ............................... 382

1. Lack of Autonomy......................... 383

a. Reliance on the Billable Hour............. 383

b. Low Decision Latitude .................. 385

2. Lack of Relatedness: Adversarial System ............ 387

3. Extrinsic Values and Motivations ............... 387

III. Ignoring the Moral Case for LaWyer Well-Being ...... 388

A. The Profit-Centered Practice: Commodification of Law

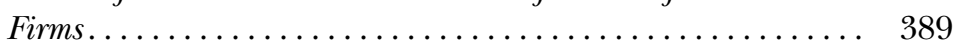

B. Stigma and Barriers to Treatment ................ 392

IV. The Business Case for Promoting and Prioritizing

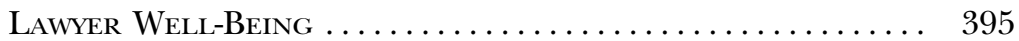

A. The Costs of Undermining Lawyer Well-Being ............ 396

1. Lawyer Discipline: Malpractice and Sanctions......... 397

2. Absenteeism and "Presenteeism" ................ 397

3. Replacement Costs and High Attrition.............. 400

B. Incremental Efforts to Address Lawyer Well-Being.......... 400

C. The Financial Benefits of Lasting and Meaningful Change .. 406

1. Performance: Client Demands for Efficiency ......... 408

2. Retention ................................ 413

3. Recruiting Younger Lawyers: Choices for the New

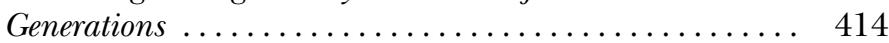

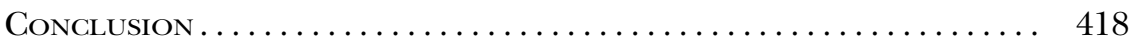


Reich: Capitalizing on Healthy Lawyers: The Business Case for Law Firms

INTRODUCTION

$\mathrm{G}$

ABRIEL MacConaill was a partner in the bankruptcy group of the international law firm Sidley Austin LLP. ${ }^{1}$ Resident in the firm's Los Angeles office, "he felt like he was doing the work of three people" and worked so hard on a bankruptcy filing that "he was in distress and . . . work[ed] himself to exhaustion"; however, he refused to go to the emergency room, because, as he told his wife: "You know, if we go, this is the end of my career." ${ }^{2}$ Then, on the morning of Sunday, October 14, 2018, he received an email and "had to go" to the office to "put something together." 3 drove to his office, "taking his gun with him, and shot himself in the head in the sterile, concrete parking structure of his high-rise office building." 4 He was forty-two.

In an open letter written one month after his death, his wife wrote simply: “Big Law' killed my husband."

In July 2015, Peter, a partner at the Silicon Valley office of the law firm Wilson Sonsini Goodrich \& Rosati LLP, "died a drug addict, felled by a systemic bacterial infection common to intravenous users." 6 He "lived in a state of heavy stress," as he "obsessed about the competition, about his compensation, about the clients, their demands, and his fear of losing them. He loved the intellectual challenge of his work but hated the combative nature of the profession, because it was at odds with his own nature." " His last phone call was for work: "vomiting, unable to sit up, slipping in and out of consciousness, [he] had managed, somehow, to dial into a conference call."

As he was being eulogized during his memorial service, "[q]uite a few" of his colleagues "were bent over their phones, reading and tapping

1. Joanna Litt, 'Big Law Killed My Husband': An Open Letter from a Sidley Partner's Widow, Aм. LAw. (Nov. 12, 2018, 9:00 AM), https://www.law.com/americanlawyer /2018/11/12/big-law-killed-my-husband-an-open-letter-from-a-sidley-partnerswidow/ [https://perma.cc/6PD5-RZNQ].

2. $I d$.

3. $I d$.

4. $I d$.

5. Id. While MacConaill's wife acknowledged that "Big Law" did not directly kill him, as he "had a deep, hereditary mental health disorder and lacked essential coping mechanisms," she observed that "these influences, coupled with a highpressure job and a culture where it's shameful to ask for help, shameful to be vulnerable, and shameful not to be perfect, created a perfect storm." Id.

6. Eilene Zimmerman, The Lawyer, the Addict, N.Y. Times (July 15, 2017), https:/ /www.nytimes.com/2017/07/15/business/lawyers-addiction-mental-

health.html [https://perma.cc/B7MA-SDSH]. Ms. Zimmerman, Peter's ex-wife, declined to use Peter's surname in her article to "protect the privacy of [their] children and Peter's extended family." Id.

7. $I d$.

8. $I d$. 
out emails. Their friend and colleague was dead, and yet they couldn't stop working long enough to listen to what was being said about him."9

These two harrowing stories are hardly unique. Indeed, for more than thirty years, a significant number of studies, articles, and reports have demonstrated the prevalence of depression, anxiety, and addiction in the legal profession. ${ }^{10}$ Throughout this time, there have been just as many calls for the profession to make changes to promote, prioritize, and improve lawyer well-being, ${ }^{11}$ particularly as many aspects of the current law firm model exacerbate mental health and addiction issues, ${ }^{12}$ as well as overall lawyer unhappiness and dissatisfaction. ${ }^{13}$

9. Id:; see also generally Eilene Zimmerman, Smacked: A Story of White-Collar Ambition, Addiction, And Tragedy (2020).

10. See, e.g., Connie J.A. Beck, et al., Lawyer Distress: Alcohol-Related Problems and Other Psychological Concerns Among a Sample of Practicing Lawyers, 10 J.L. \& Health 1 (1995); G. Andrew H. Benjamin et al., The Prevalence of Depression, Alcohol Abuse, and Cocaine Abuse Among United States Lawyers, 13 Int'L J. L. \& Psychiatry 233 (1990) [hereinafter Benjamin et al., The Prevalence of Depression]; Patrick R. Krill et al., The Prevalence of Substance Use and Other Mental Health Concerns Among American Attorneys, 10 J. Addiction Med. 46 (2016); see also William W. Eaton et al., Occupations and the Prevalence of Major Depressive Disorder, 32 J. Occupational Med. 1079, 1085 tbl.3 (1990). Similar scholarship over this time period also demonstrates the widespread mental health and addiction issues among law students. See infra Section II.B.

11. See, e.g., Benjamin et al., The Prevalence of Depression, supra note 10, at 245 ("The national United States and the regional state Bar Associations should avoid the phenomenon of institutional denial and attempt to reach their members before symptoms lead to malpractice or unethical practice."); see also, e.g., Rick B. Allan, Alcoholism, Drug Abuse and Lawyers: Are We Ready to Address the Denial?, 31 Creighton L. Rev. 265 (1997); Laura Rothstein, Law Students and Lawyers with Mental Health and Substance Abuse Problems: Protecting the Public and the Individual, 69 U. Pitt. L. Rev. 531 (2008).

12. See infra Section II.C.

13. There is a myriad of scholarship that refers to "happiness" (or, more particularly, a lack thereof) within the legal profession. See, e.g., NANCy Levit \& Douglas O. Linder, The Happy Lawyer: Making a Good Life in the Law (2010); Lawrence S. Krieger \& Kennon M. Sheldon, What Makes Lawyers Happy? A DataDriven Prescription to Redefine Professional Success, 83 GEO. WASH. L. Rev. 554 (2015) [hereinafter Krieger \& Sheldon, What Makes Lawyers Happy?]; Patrick J. Schiltz, On Being a Happy, Healthy, and Ethical Member of an Unhappy, Unhealthy, and Unethical Profession, 52 VAND. L. Rev. 871 (1999); Martin E.P. Seligman et al., Why Lawyers Are Unhappy, 23 Cardozo L. Rev. 33 (2001). This scholarship, to which this Article cites, examines "happiness" in the context of lawyer mental health, addiction, distress, or a deeper level of lawyer satisfaction (such as subjective well-being as that is understood under the tenets of self-determination theory-see infra notes 123-127 and accompanying text) rather than mere notions of transient happiness or job "satisfaction."

Empirical studies demonstrate the distinctions between the former and the latter. With respect to the latter, studies assessing levels of abstract "happiness" and job "satisfaction" suggest that "[a]s a general matter, lawyers are relatively satisfied with their job/careers." See Jerome M. Organ, What Do We Know About the Satisfaction/Dissatisfaction of Lawyers? A Meta-Analysis of Research on Lawyer Satisfaction and Well-Being, 8 U. ST. Thomas L.J. 225, 261-62 (2011); see also id. at 261 (concluding that, upon an analysis of studies from the prior twenty-five years, an average of $78.8 \%$ of lawyers describe themselves as "satisfied"). As one example, in a thirty- 
Reich: Capitalizing on Healthy Lawyers: The Business Case for Law Firms

Despite these calls for change, the pervasiveness of mental health and addiction issues among lawyers has persisted, if not increased. ${ }^{14}$ Recognizing that this pervasiveness "can no longer be ignored," 15 in a 2017 report entitled The Path to Lawyer Well-Being, the American Bar Association's National Task Force on Lawyer Well-Being issued a "call to action" for the profession to "get serious about the substance use and mental health of ourselves and those around us." 16 Partially in response to the report, the profession has made some inroads in addressing these problems. For example, some law firms have begun to take proactive steps to improve their lawyers' well-being, ${ }^{17}$ and as of May 2020, 133 law firms signed a pledge to support the ABA's campaign to address mental health and addiction issues in the profession-which the ABA hoped that "all legal employers" would sign by January 1, 2019. ${ }^{18}$

Notwithstanding the recognized need and these calls for change, the majority of firms have "turned a blind eye to widespread health problems" that pervade the profession. ${ }^{19}$ This Article argues that this "blind eye" exists in large part because firms have not had a financial incentive to address the problem. Law firms have increasingly moved from being "central players in a noble profession to a collection of profit-maximizing enterprises," and this pursuit of profits has come at the expense of the well-

year longitudinal study of 1990 University of Virginia Law School graduates, $77.4 \%$ of respondents reported being satisfied with their decision to become a lawyer and nearly $91 \%$ reported being satisfied with their lives generally. John Monahan \& Jeffrey Swanson, Lawyers at the Peak of Their Careers: A 30-Year Longitudinal Study of Job and Life Satisfaction, 16 J. Legal EMPIRICAL STUd. 4, 19, 21-22 (2019). However, the results of these studies, while helpful, do not speak to and are not inconsistent with the empirical, scientifically validated evidence of widespread lawyer mental health and addiction issues. See David L. Chambers, Overstating the Satisfaction of Lawyers, 39 L. \& Soc. INQuiRy 313, 315, 330 (2014) (“[O]nly a small proportion of attorneys hold negative views overall about their jobs or careers ... [but] to the extent that the negative literature reports large numbers of beleaguered lawyers who feel unhappy or ambivalent about many aspects of their work, nothing in the survey literature, properly viewed, should be seen as inconsistent."); $c f$. Levit \& LindER, supra, at 32 ("Claiming that you're happy . . . appears to be nearly universal, as long as you're not living in a war zone, on the street, or in extreme emotional or physical pain." (internal quotation marks omitted) (quoting Sue M. Halperin, Are You Happy?, N.Y. Rev. Books (Apr. 3, 2008), https:// www.nybooks.com/articles/2008/04/03/are-you-happy/ [https://perma.cc/ PS6D-CMQV])).

14. Compare infra notes 25-43 and accompanying text, with infra notes 59-67 and accompanying text.

15. Nat'l Task Force on Lawyer Well-Being, Am. Bar Ass'n, The Path to Lawyer Well-Being: Practical Recommendations for Positive Change 11 (2017), https://www.americanbar.org/content/dam/aba/images/abanews/ ThePathToLawyerWellBeingReportFINAL.pdf [https://perma.cc/B3WH-DDTF] [hereinafter The Path to Lawyer Well-Being].

16. Id. at 10 .

17. See infra notes 298-303 and accompanying text.

18. See infra notes 292-297 and accompanying text.

19. The Path to Lawyer Well-Being, supra note 15, at 12. 
being of the lawyers who generate them. ${ }^{20}$ As firms' short-term goal of maximizing annual profits has become their principal long-term goal, lawyer distress has risen along with partner profits. Put differently, the commodification of the legal profession is an "unambiguous contributor" to the pervasiveness of lawyer distress. ${ }^{21}$ Additionally, many law firms also are reticent to change in part because of the stigma surrounding mental health or addiction issues-all of which can affect the bottom line. ${ }^{22}$

Since the moral- and humanitarian-based cases for firms to promote and prioritize lawyer well-being in the literature largely have been ignored, this Article is the first to make the business case to do so. In particular, this Article argues that systemic changes designed to provide support and resources to firm lawyers will avoid costs associated with lawyer mental health and addiction issues and, more importantly, create efficiencies that will increase firms' long-term financial stability and growth. Further, this Article argues that, given a confluence of societal, industrial, and generational factors, now is the time for firms to focus on the health and wellbeing of their lawyers.

Part I of this Article provides an overview of the studies of the last three-plus decades demonstrating the prevalence of depression, anxiety, and other mental health concerns as well as substance abuse in the legal profession. It shows that lawyers have consistently suffered from these issues in much greater proportion than the general population. It also demonstrates that the profession has long understood the need to change the paradigm to support lawyers struggling with mental illness and addiction, but it has largely remained silent in the face of calls for such change.

Part II examines the personal and professional risk factors that negatively affect mental health and addiction as well as lawyer distress generally. In particular, it addresses whether and to what extent there exists a lawyer "personality" that is inherently predisposed to mental illness and addiction. Further, relying largely on self-determination theory and related research, this Part explores how both law school and law practice can contribute to and exacerbate lawyer mental illness, addiction, and mental distress.

Part III sets out why law firms have turned a "blind eye" to lawyer wellbeing. Appeals to law firms-made largely on moral and humanitarian grounds-to provide support and resources to their lawyers and to make systemic changes to their practices largely have not resulted in meaningful change, and this Part analyzes why firms have had little incentive-both financial and cultural-to change their models.

Finally, Part IV makes the business case for law firms to promote and prioritize lawyer well-being. This Part first analyzes the different direct

20. Steven J. Harper, The Lawyer Bubble: A Profession in Crisis 70 (2013).

21. Id. at 96-97; see also generally infra notes 200-232 and accompanying text.

22. Sara Randazzo, Law Firms Tackle a Taboo-On-Site Psychologists for Lawyers Become More Common; Some Bristle at the Idea, WALL ST. J., May 22, 2017, at B2. 
and indirect costs that firms face in failing to address lawyer mental health and addiction issues, from a rise in malpractice claims and sanctions to a decline in productivity to costs associated with high lawyer attrition. This Part also argues that now is the time for the law firm paradigm to shift to one that prioritizes lawyer well-being.

\section{Mental Illness and Addiction in the Legal Profession:}

\section{An Empirical Overview}

The first major studies identifying lawyer mental health and substance abuse problems were conducted thirty years ago. ${ }^{23}$ These studies showed "significant elevated levels of depression" and a high percentage of "problem drinkers" among lawyers, particularly as compared with both members of other professions and the general population. ${ }^{24}$ In the three decades since, not much has changed.

In 1990, Andrew Benjamin, Elaine Darling, and Bruce Sales published an empirical study about lawyers in the State of Washington who suffered from depression, alcoholism, and cocaine abuse. ${ }^{25}$ This study followed a 1986 study of Arizona law students by Benjamin, Sales, and others, which found that "law students and lawyers suffered from depression at a rate twice to four times what would be expected in the general population." 26

Confirming the findings of the 1986 study, the 1990 study found "no statistical differences" between the levels of depression among Arizona law students, young lawyers, and Washington lawyers. ${ }^{27}$ Specifically, the Washington study found that $19 \%$ of lawyers "suffered from statistically significant elevated levels of depression," with "most . . . experiencing suicidal ideation." 28 The study also found that $18 \%$ of lawyers were "problem drinkers"-approximately twice the alcohol abuse or dependency rates for

23. See Benjamin et al., The Prevalence of Depression, supra note 10; Eaton et al., supra note 10.

24. Benjamin et al., The Prevalence of Depression, supra note 10, at 240-41; see also Eaton et al., supra note 10, at 1085 tbl.3 (demonstrating that lawyers have the highest odds ratio for major depressive disorder among 104 professions at a rate of 3.6 times the general population).

25. Benjamin et al., The Prevalence of Depression, supra note 10, at 235-36.

26. Id. at 234 (citing G. Andrew H. Benjamin et al., The Role of Legal Education in Producing Psychological Distress Among Law Students and Lawyers, 11 AM. B. Found. REs. J. 225 (1986) [hereinafter Benjamin et al., Role of Legal Education]); see also id. at 247 (finding that " $17-40 \%$ of law students and alumni in [the] study suffered from depression, while $20-45 \%$ of the same subjects suffered from other elevated symptoms"). For a detailed discussion of this study, see infra notes 118-121 and accompanying text.

27. Benjamin et al., The Prevalence of Depression, supra note 10, at 240.

28. Id. at 240-41. 
adults in the United States. ${ }^{29}$ Depression rates remained the same across lawyers' length of practice, but the rate of problem drinkers increased. ${ }^{30}$

Also in 1990, researchers at Johns Hopkins University studied the rates of major depressive disorder ${ }^{31}$ among individuals across 104 professions. ${ }^{32}$ While $3 \%-5 \%$ of the adult population suffers from major depressive disorder, these researchers found that $10 \%$ of lawyers do so. ${ }^{33}$ Moreover, when adjusted for sex, race, education, and current employment, lawyers have the highest odds ratio for major depressive disorder among the professions studied-at a rate 3.6 times the general population. ${ }^{34}$

Five years later, Benjamin, Sales, and Connie Beck published results of a study returning to the data and subjects of Benjamin and Sales's 1990 study. ${ }^{35}$ They further analyzed the earlier data by: (1) considering additional demographic variables and analyzing how they may correlate with levels of distress and alcohol use; (2) analyzing all types of distress; and (3) "using sequential canonical analysis," determining "the degree of relationship of the predictor variables to the different categories of psychological distress, a global measure of psychological distress, and current and lifetime alcohol-related problems." 36

Their in-depth analysis yielded findings that further supported Benjamin and Sales's earlier studies as well as the Hopkins study. For instance, they concluded that $20 \%$ of female lawyers were above the clinical cutoff

29. Id. at 241 (citation omitted). For purposes of the study, "problem drinkers" are defined as those "likely [to be] abusive of or dependent on alcohol." Id. at 237.

30. Id. Specifically, the rate of problem drinkers rose from approximately $18 \%$ of those who practiced between two and twenty years to $25 \%$ of those who practiced twenty years or more. Id. The study notes that this likely is because "[a]lcohol abuse and dependency is a chronic and progressive disease [, and] it can take years to become evident in some cases. As a result, those who have practiced longer appear to be more susceptible to developing problem drinking." Id.

31. A person has "major depressive disorder" if: (a) they have five or more of the following symptoms over the same two-week period: (i) "[d]epressed mood"; (ii) " $[\mathrm{m}]$ arkedly diminished interest or pleasure in all, or almost all, activities most of the day"; (iii) "[s]ignificant weight loss . . or weight gain"; (iv) "[i]nsomnia or hyperinsomnia"; (v) "[p] sychomotor agitation or retardation"; (vi) "fatigue or loss of energy"; (vii) "[f] eelings of worthlessness or excessive or inappropriate guilt .. . nearly every day"; (viii) "[d]iminished ability to think or concentrate, or indecisiveness, nearly every day"; and (ix) "[r] ecurrent thoughts of death . . . or suicidal ideation"; (b) "[their] symptoms cause clinically significant distress or impairment in social, occupational, or other important areas of function"; and (c) the symptoms are not attributable to effects of a substance or another medical or psychological condition. Am. Psych. Ass'n, Diagnostic and Statistical Manual of Mental DisORDERs 160-61 (5th ed. 2013).

32. Eaton et al., supra note 10 , at 1079 .

33. Id. at 1081-82 tbl.2.

34. Id. at 1085 tbl.3.

35. Beck et al., supra note 10.

36. Id. at 12 . 
for anxiety and $16 \%$ were above the clinical cutoff for depression, ${ }^{37}$ and male lawyers were above the clinical cutoffs for these distresses at $28 \%$ and $20 \%$, respectively. ${ }^{38}$ As they observe: "The percentage of lawyers scoring above the cutoff is alarming in that the expected percentage of people scoring above the benchmark is only 2.27\%." 99 Further, these numbers do not change markedly over the course of a lawyer's career. ${ }^{40}$ Similarly, they report an "astounding number of lawyers [have] a high likelihood of developing alcohol-related problems," 41 with "[a]pproximately $70 \%$ of lawyers . . . likely to develop alcohol problems over their lifetime," a figure that both is "consistent across all years," and is more than five times greater than the $13.7 \%$ rate of lifetime prevalence of alcohol abuse or dependence for the general population. ${ }^{42}$ As a result of their study, they ultimately conclude that "psychological distress, in its many forms, is likely to affect newly practicing lawyers in a similar manner regardless of the state in which they practice," and that "throughout their career span, a large percentage of practicing lawyers are experiencing a variety of significant psychological distress symptoms well beyond that expected in a normal population." 43

Other studies reached similarly striking conclusions. For instance, a 1987 study performed as part of a doctoral dissertation found that $32 \%$ of Florida lawyers "reported feeling depressed at least once a week," ${ }^{44}$ and a

37. Id. at 23 tbl.4 \& 25 . They also concluded that approximately $27 \%$ of female lawyers scored above the clinical cutoff for interpersonal sensitivity, $20 \%$ for social alienation and isolation, $15 \%$ for obsessive-compulsiveness, and $11 \%$ for hostility. $I d$.

38. Id. at $23 \&$ tbl.4. They also concluded that approximately $30 \%$ of male lawyers scored above the clinical cutoff for interpersonal insensitivity, $25 \%$ for social alienation and isolation, $20 \%$ for obsessive-compulsiveness, $14 \%$ for paranoid ideation, $7 \%$ for phobic anxiety, and $7 \%$ for hostility. Id. at 23 tbl.4.

39. Id. at 23 .

40. See id. at $46-48$ \& tbls. 12 \& 13.

41. Id. at 50-51.

42. Id. at 51 .

43. Id. at 57. They also conclude:

A picture emerges that does not bode well for harmonious family life. Lawyers have been slowly increasing the number of hours they work over time and taking only two weeks or less of annual vacation. The percentage of lawyers who report that they do not have enough time for themselves or their families has increased 33\% from 1984 to 1990. Although this study's findings indicate limited differences in feelings of stress between lawyers and the general population, another researcher has found that $32.5 \%$ of his sample of lawyers indicate that they use alcohol regularly as a coping mechanism to reduce stress. That a critical member of the family is working more, taking less time off, spending less time with the family, and potentially using alcohol to cope with high degrees of psychological distress suggests an impending major crisis for lawyers' family life.

Id. at 58-59 (footnotes omitted).

44. G. Andrew H. Benjamin et al., Comprehensive Lawyer Assistance Programs: Justification and Model, 16 LAw \& Psychol. Rev. 113, 114 (1992) [hereinafter Benjamin et al., Comprehensive Lawyer Assistance Programs] (citing Allan McPeak, Lawyer 
1988 study performed as part of another doctoral dissertation found that $79 \%$ of lawyers in Wisconsin "used alcohol regularly or sometimes to reduce stress." 45 Further, a 1991 report by the North Carolina Bar Association reported that over $24 \%$ of that state's lawyers suffer from depression, more than $25 \%$ display "anxiety symptoms," and over $22 \%$ have been diagnosed with a "stress-related disease" such as ulcers, hypertension, or coronary artery disease. ${ }^{46}$ Shockingly, $11 \%$ of North Carolina lawyers surveyed "admitted they consider taking their lives once a month." 47

Additionally, studies published during this time have found a correlation between substance abuse and lawyer discipline, concluding that a disproportionate number of "major attorney disciplinary cases" were a result of lawyer substance abuse. ${ }^{48}$ For instance, a report cited by the American Association of Law Schools in its 1993 Report on Problems of Substance Abuse in Law Schools found that substance abuse was "involved" in $50 \%$ to $75 \%$ of such cases. ${ }^{49}$ An earlier survey conducted by the American Bar Association in New York and California found that "50-70 percent of all disciplinary cases involved alcoholism."50

Occupational Stress (1987) (unpublished Ph.D. dissertation, Florida State University)).

45. Id. at 115 (citing Dennis W. Kozich, An Analysis of Stress Levels and Stress Management Choices of Attorneys in the State of Wisconsin (1988) (unpublished Ph.D. dissertation, University of Wisconsin-Madison)).

46. N.C. Bar Ass'n, Report of the Quality of Life Task Force and RecomMENDATIONS 4 (1991), https://www.nclap.org/wp-content/uploads/2014/07/ 1991_QoL_summary.pdf [https://perma.cc/F9R2-X7B9].

47. Susan Swaim Daicoff, Lawyer, Know Thyself: A Psychological Analysis of Personality Strengths and Weaknesses 8 (2004) (internal quotation marks omitted) (citation omitted).

48. Am. Ass'n of Law Schools, Report of the AALS Special Committee on Problems of Substance Abuse in the Law Schools, 44 J. Legal Educ. 35, 36 (1994).

49. Id. Additionally, Benjamin and his colleagues noted in their 1990 report that the ABA determined that "27 percent of the discipline cases in the United States involved alcohol abuse." Benjamin et al., The Prevalence of Depression, supra note 10 , at 243 . However, they opine that the actual figure "may actually be much higher, however, because not all state and county bar associations report their disciplinary cases. In addition, under-reporting has occurred because state bar associations were unable to identify alcohol abusing lawyers who became part of the disciplinary process. Until very recently, very few bar associations considered the causes for the lawyer infractions." Id. at 244. 118.

50. Benjamin et al., Comprehensive Lawyer Assistance Programs, supra note 44, at 
Reich: Capitalizing on Healthy Lawyers: The Business Case for Law Firms

In response to the pervasiveness of mental distress and addiction in the legal profession, many practitioners ${ }^{51}$ and scholars $^{52}$ have called for changes to the profession. Among the largest changes was the development and expansion of lawyer assistance programs. ${ }^{53}$ These programs generally provide support services to lawyers and legal professionals with mental health and substance abuse issues. ${ }^{54}$ Currently, all fifty states and the District of Columbia have some sort of lawyers assistance program, ${ }^{55}$ most of which were established in the last thirty years. ${ }^{56}$

Notwithstanding these calls for change, such change has been hard to come by. In the intervening years, articles and books have highlighted lawyers' struggles with unhappiness and mental health and addiction issues, ${ }^{57}$ with one such article asking simply: "Why are lawyers killing themselves?" 58

51. See, e.g., J. Nick Badgerow, Apocalypse at Law: The Four Horsemen of the Modern Bar-Drugs, Alcohol, Gambling and Depression, 18 Prof. L. 2, 2 (2007); G. Andrew H. Benjamin, Reclaim Your Practice, Reclaim Your Life, Trial, Dec. 2008, at 30, https:/ /depts.washington.edu/petp/Reclaim_Your_Practice_\%20Reclaim_Your_Life.pdf [https://perma.cc/QJ8G-FUAA]; Ted David, Can Lawyers Learn to Be Happy?, PRACTICAL Law., Aug. 2011, at 29; Linda M. Rao, Time for an Ideality Check: If You Had Your Ideal Job, Would You Be Satisfied?, 22 BARRISTER 13 (1995).

52. See, e.g., Allan, supra note 11; Ariram Elwork \& G. Andrew H. Benjamin, Lawyers in Distress, 23 J. Psychiatry \& L. 205 (1995); Schiltz, supra note 13.

53. See Am. Bar Ass'n, Comm'n on Lawyer Assistance Programs, 2014 Comprehensive Survey of Lawyer Assistance Programs (2015), https://www.americanbar.org/content/dam/aba/administrative/lawyer assistance/is/colap_2014_comprehensive_survey_of_laps.authcheckdam.pdf [https://perma.cc/R36Y-Z3HF] [hereinafter ABA Survey of LawYer Assistance Programs].

54. See generally id.

55. Id. at 1-2, A-3, A-4. The ABA's report only identifies forty-eight states and the District of Columbia in its survey, as programs from neither Nevada nor North Dakota replied. However, Nevada's Lawyer Assistance Program was established in 2013, see State Bar of Nevada, Nevada Lawyers Assistance Program (NLAP), http://www.nvbar.org/member-services-3895/nlap/ [https://perma.cc/G3TYE89Z] (last visited May 7, 2020), and North Dakota's in 2004, see N.D. Admin Code 49 (2004).

56. Although the first few Lawyers Assistance Programs (LAPs) were founded in the mid-1970s, thirty-two LAPs were founded since 1990. See ABA Survey of Lawyer Assistance Programs, supra note 53, at 3 fig. 1; see also N.D. Admin. Code 49; Nevada Lawyers Assistance Program (NLAP), supra note 55.

57. See, e.g., Brian Cuban, The Addicted Lawyer: Tales of the Bar, Booze, Blow, and Redemption (2017); Harper, supra note 20; Douglas Litowitz, The Destruction of Young Lawyers: Beyond One L (2006); Jean Stefancic \& Richard Delgado, How lawyers lose Their Way: A Profession Fails Its Creative Minds (2005); Patrick Krill, Why Lawyers Are Prone to Suicide, CNN (Jan. 21, 2014, 10:15 AM), https://www.cnn.com/2014/01/20/opinion/krill-lawyers-suicide/index.html [https://perma.cc/RLF5-C45T]; Zimmerman, supra note 6 .

58. Rosa Flores \& Rose Marie Acre, Why Are Lawyers Killing Themselves?, CNN (Jan. 20, 2014), http://www.cnn.com/2014/01/19/us/lawyer-suicides/index.html [https://perma.cc/7HZW-9KT3]. Among other things, Flores and Acre noted that Kentucky had fifteen known lawyer suicides over a four-year period, South Carolina had six known lawyer suicides over an eighteen-month period in 2007-2008, and Oklahoma had one known lawyer suicide per month in 2004. Id. 
A comprehensive 2016 study confirmed that not much, if anything, has changed in a quarter-century. This study, conducted by Patrick R. Krill, Ryan Johnson, and Linda Albert for the ABA Commission on Lawyer Assistance Programs and the Hazelden Betty Ford Foundation (the Krill Study), ${ }^{59}$ found numbers consistent with-and in some cases, more troubling than-the earlier studies. The Krill Study surveyed nearly 13,000 practicing lawyers across the country and across varying demographics and types of legal practice. ${ }^{60}$ It found that "rates of problematic drinking" were "generally consistent" with those reported in Benjamin, Sales, and Beck's 1990 study, with $20.6 \%$ to $36.4 \%$ of those surveyed qualifying as problem drinkers. ${ }^{61}$

However, the Krill Study found "considerably higher rates of mental health distress" than those found in the earlier studies. ${ }^{62}$ In particular, it found 28.3\% of lawyers surveyed suffer from some level of depression, $19.3 \%$ suffer from some level of anxiety, and $22.7 \%$ suffer from some level of stress. ${ }^{63}$ Further, $45.7 \%$ of surveyed lawyers reported concerns with depression at some point in their career, and $61.1 \%$ reported concerned with anxiety at some point in their career. ${ }^{64}$ An additional $11.5 \%$ of participants reported suicidal thoughts at some point during their career. ${ }^{65}$ Moreover, the study found that lawyers have the highest rates of both problem drinking and depression in their first ten years of practice as compared with later years, and those working in private practice also have higher rates of both than those in other work environments. ${ }^{66}$ In particu-

59. Krill et al., supra note 10.

60. See id. at $47 \&$ tbl.1, 48 tbl.2.

61. Id. at 51; see also id. at 49 tbl.3. The Krill Study evaluated alcohol use using the Alcohol Use Disorders Identification Test, a ten-item "self-report developed by the World Health Organization (WHO) to screen for hazardous use, harmful use, and the potential for alcohol dependence." Id. at 47.

62. Id. at 51. The Krill Study evaluated depression, anxiety, and stress by utilizing the Depression Anxiety Stress Scales-31, a "self-report instrument consisting of three 7-item subscales assessing symptoms" of each. Id. at 48.

63. $I d$. at 50 tbl.4. These findings are not unique to American lawyers. For example, a 2014 study of Australian lawyers found that $37 \%$ of those sampled experienced moderate to extremely severe depressive symptoms, $31 \%$ experienced moderate to extremely severe anxiety symptoms, and $49 \%$ experienced moderate to extremely severe stress symptoms; further $35 \%$ of those lawyers sampled qualified as hazardous or harmful drinkers. Adele J. Bergin \& Nerina L. Jimmieson, Australian Lawyer Well-Being: Workplace Demands, Resources $\mathcal{E}$ the Impact of Time-Billing Targets, 21 Psychiatry, Psychol. \& L. 427, 434 (2014). Additionally, a 2009 study of over 900 Australian solicitors and over 750 Australian barristers found that $31 \%$ of solicitors and $16.7 \%$ of barristers suffer from high or very high distress, as compared with $13 \%$ of the general population. Norm Kelk et Al., Brain \& Mind RESearch Inst., U. Sydney, Courting the Blues: Attitudes Towards Depression in Australian Law Students and Legal Professionals 12 (2009), https://law.uq .edu.au/files/32510Courting-the-Blues.pdf [https://perma.cc/GV7M-GARN].

64. Krill et al., supra note 10 , at 50 .

65. Id.

66. Id. at 51 . 
Reich: Capitalizing on Healthy Lawyers: The Business Case for Law Firms

lar, the study found that $32 \%$ of lawyers under thirty are problem drinkers. ${ }^{67}$

In light of, among other things, the Krill Study and a similar 2016 study of law students, ${ }^{68}$ in August 2016, entities within and outside the ABA created the National Task Force on Lawyer Well-Being (the Task Force). ${ }^{69}$ The Task Force recognized that the prevalence of mental health and addiction issues in the profession "are incompatible with a sustainable legal profession," and argued that " $[\mathrm{t}]$ o maintain confidence in the profession, to meet the need for innovation in how we deliver legal services, to increase access to justice, and to reduce the level of toxicity that has allowed mental health and substance use disorders to fester among our colleagues, we have to act now."70

To that end, the Task Force issued a report in August 2017, concluding that "lawyer well-being issues can no longer be ignored."71 The report, entitled The Path to Lawyer Well-Being: Practical Recommendations for Positive Change, issued a "call to action" for the profession to "get serious about the substance use and mental health of ourselves and those around us."72 It provided "three reasons to take action": (1) "organizational effectiveness"; (2) "ethical integrity"; and (3) "humanitarian concerns."73 First, the report concludes (as this Article demonstrates) ${ }^{74}$ that "lawyer well-being contributes to organizational success," as "lawyer health is an important form of human capital that can provide a competitive advantage."75 Second, the report concludes that "lawyer well-being influences ethics and professionalism," with "40 to 70 percent of disciplinary proceedings and

67. Id. at 49 tbl.3; id. at 51.

68. See Jerome M. Organ et al., Suffering in Silence: The Survey of Law Student Well-Being and the Reluctance of Law Students to Seek Help for Substance Use and Mental Health Concerns, 66 J. Legal Educ. 116 (2016). This study, resulting from a survey of over 3,300 law students, found that "consumption of alcohol among law students appears to have become more prevalent than two decades ago," $i d$. at 127 , and $32 \%$ of respondents have used illegal drugs or prescription drugs without a prescription in the prior twelve months. Id. at 145 . Further, the study found that $17 \%$ of law students experienced some level of depression, $37 \%$ reported some level of anxiety, and $6 \%$ reported suicidal ideation within the last twelve months. Id. at $136-39$.

69. The Task Force is a "collection of entities within and outside the ABA"; it was "conceptualized and initiated by the ABA Commission on Lawyer Assistance Programs (CoLAP), the National Organization of Bar Counsel (NOBC), and the Association of Professional Responsibility Lawyers," and created in August 2016. Bree Buchanan \& James C. Coyle, National Task Force on Lawyer Well-Being: Creating a Movement to Improve Well-Being in the Profession, Aм. B. Ass'N (Aug. 14, 2017), https://www.americanbar.org/content/dam/aba/images/abanews/ThePathTo LawyerWellBeingReportFINAL.pdf [https://perma.cc/W8ES-NRUB].

70. The Path to Lawyer Well-Being, supra note 15.

71. Id. at 7 .

72. Id. at 10 .

73. $I d$. at 8 .

74. See infra Section IV.C.

75. The Path to Lawyer Well-Being, supra note 15, at 8 (footnote omitted); see also id. at 1 ("To be a good lawyer, one has to be a healthy lawyer."). 
malpractice claims against lawyers involv[ing] substance use or depression, and often both." 76 Finally, the report concludes that "from a humanitarian perspective, promoting well-being is the right thing to do." 77

The report goes on to make various recommendations for a series of "stakeholders"-judges, ${ }^{78}$ regulators, ${ }^{79}$ legal employers, ${ }^{80}$ law schools, ${ }^{81}$ bar associations, ${ }^{82}$ lawyers' professional liability carriers, ${ }^{83}$ and lawyers assistance programs ${ }^{84}$ - to combat the "blind eye" that the legal profession has turned "to widespread health problems." 85 The recommendations to all stakeholders include "buy-in and role modeling" from the top down and taking steps to minimize the stigma of mental health and substance abuse disorders and to facilitate and encourage employees to seek and attain appropriate help. ${ }^{86}$

By its own admission, the report "makes a compelling case that the legal profession is at a crossroads," as the "current course" of "widespread disregard for lawyer well-being and its effects[] is not sustainable." 87 It concludes that the profession has "ignored this state of affairs long enough," and that "[a]s a profession, we have the capacity to face these challenges and create a better future for our lawyers" that is both "sustainable" and in pursuit of "the highest professional standards, business practices, and ethical ideals." 88

\section{Why This Happens: Professional Risk Factors Affecting Mental Health and Addiction}

There is no one answer for why lawyers disproportionately suffer from mental health and addiction problems compared to the general population. Yet the fact remains that they do. This Article does not minimize the existence of biological, chemical, and genetic conditions that predispose individuals to mental illness or addiction. These cannot, and should not, be discounted or overlooked by individuals with such predispositions. Nevertheless, what this Article does argue, and what is beyond dispute, is that lawyer distress is systemic - that there exists a strong correlation between the legal profession and lawyer distress that can no longer be ig-

76. Id. at 8 (footnote omitted).

77. Id. at 9 .

78. Id. at $22-24$.

79. Id. at $25-30$.

80. Id. at 31-34.

81. Id. at 35-40.

82. Id. at 41-42.

83. Id. at 43-44.

84. Id. at 45-46.

85. Id. at 12 .

86. Id. at 12-13.

87. Id. at 47 .

88. Id. 
Reich: Capitalizing on Healthy Lawyers: The Business Case for Law Firms

nored ${ }^{89}$ Some of the potential systemic sources of lawyer distress include: (1) the possible existence of an inherent "lawyer personality"; (2) the law school experience; and (3) several aspects of law practice. ${ }^{90}$

\section{A. "Lawyer Personality"}

It has long been assumed that the legal profession is composed of individuals who are inherently predisposed to being "pessimistic, unhappy, and more prone to destructive addictions than other occupational groups." 91 Indeed, accounts of the "depressing character of legal study" date back to at least the Middle Ages. ${ }^{92}$ Yet the question of whether lawyers as a group are inherently prone to struggles with mental illness and addiction is far from settled, and the most recent research suggests that the stereotypical "lawyer personality" does not exist.

Early studies support the view that there are inherent qualities in individuals who seek to become or who are successful lawyers. These studies conclude that "personality traits most common among lawyers are not those associated with happy people," 93 and that lawyers exhibit "several personality traits which tend to intensify lawyers' stress levels," such as low self-esteem, egotism, inflexibility, workaholism, cynicism, and aggression. ${ }^{94}$

For instance, in an influential 2001 article, Martin Seligman, Paul Verkuil, and Terry Kang argue that lawyers are more successful when they

89. See Litowitz, supra note 57, at 19.

Let us be very clear on the question of causality: the legal profession makes lawyers unhappy. We must reject any suggestion that lawyers are unhappy prior to their immersion in the legal system, that these unhappy people somehow self-select their own unhappiness by subconsciously placing themselves in a depressing profession. . . . We did not bring a cloud of depression to the profession; we discovered the cloud when we got here. In other words, the problems affecting young lawyers are preId. dominately systemic, not personal.

90. When discussing these as factors that affect lawyer mental health and addiction issues, that is only to suggest, as noted above, the existence of correlations between these factors and such issues and not scientific conclusions of cause and effect. Rather, the studies and other works discussed in this section establish correlations and apparent effects of these factors on lawyer distress. Cf. Krieger \& Sheldon, What Makes Lawyers Happy?, supra note 13, at 559 n.8 (explaining how their findings "provide substantial confidence in apparent causal relationships" despite the limitation of its study focusing on correlations, particularly because of "the large sample sizes and the consistency of [their] findings with similar findings in previous related studies").

91. Margaret L. Kern \& Daniel S. Bowling III, Character Strengths and Academic Performance in Law Students, 55 J. Res. in Personality 25, 25 (2014).

92. See Peter Goodrich, Oedipus Lex: Psychoanalysis, History, Law 1-7 (1995).

93. Levit \& Linder, supra note 13, at 75.

94. Susan Daicoff, Lawyer, Know Thyself: A Review of Empirical Research on Attorney Attributes Bearing on Professionalism, 46 Am. U. L. Rev. 1337, 1417 (1997) (discussing Amiram Elwork, Stress Management for Lawyers 15 (1995)). 
have a "pessimistic 'explanatory style," 95 meaning they have a "tendency to interpret the causes of negative events in stable, global, and internal ways."96 Also known as "prudence," this perspective "requires caution, skepticism, and 'reality-appreciation," "and "enables a good lawyer to see snares and catastrophes that might conceivably occur in any given transaction." 97 This ability to anticipate problems and "issue-spot" is an essential quality for effective lawyering. ${ }^{98}$

Although this kind of pessimism is a quality of a good lawyer, it also correlates to mental distress, as it is well-documented as a major factor for depression and distress. ${ }^{99}$ Lawyers who are pessimistic in practice often have that pessimism spill into their personal lives. For instance, lawyers who spend their working hours searching for, anticipating, and agonizing over problems tend to see the worst for themselves both inside and outside of the office. ${ }^{100}$ They may also have a more negative or pessimistic view of their work and their lives and can focus on, or even catastrophize, problems in both. ${ }^{101}$ Accordingly, as Seligman, Verkuil, and Yang conclude, "pessimism that might be adaptive in the profession also carries the risk of depression and anxiety in the lawyer's personal life." 102

Beyond this penchant for pessimism, Susan Daicoff has attempted to quantify the "lawyer personality." 103 In reviewing studies done on lawyer characteristics, she concluded that on the Myers-Briggs Type Indicator personality assessment measure, lawyers disproportionately represent the "Thinking" rather than the "Feeling" type when compared to the general population. ${ }^{104}$ She concluded further that, in contrast to most of the pop-

95. Seligman et al., supra note 13, at 39; see also Jason M. Satterfield et al., Law School Performance Predicted by Explanatory Style, 15 BeHav. Sci. \& L. 95, 100-04 (1995) (determining, in a study of nearly 400 University of Virginia Law School students, that pessimistic students were more successful in law school than optimistic ones).

96. Seligman et al., supra note 13 , at 39 .

97. Id. at 41.

98. See id. ("The ability to anticipate a whole range of problems that nonlawyers do not see is highly adaptive for the practicing lawyer.").

99. See id.; cf. Beck et al., supra note 10, at 57 ("[T] he basic pattern of distress may represent the traits necessary to be a successful lawyer (obsessive-compulsiveness, interpersonal sensitivity, and anxiety) and the costs associated with those success (depression and social alienation and isolation).").

100. Seligman et al., supra note 13, at 41.

101. See, e.g., Todd David Peterson \& Elizabeth Waters Peterson, Stemming the Tide of Law Student Depression: What Law Schools Need to Learn from the Science of Positive Psychology, 9 Yale J. Health Pol'y L. \& Ethics 358, 400 (2009); see also Shawn Achor, The Happiness Advantage: How a Positive Brain Fuels Success in Work AND LifE 92-93 (2010).

102. Seligman et al., supra note 13 , at 41.

103. See, e.g., Susan Swaim Daicoff, Lawyer Know Thyself: A Psychological Analysis of Personality Strengths and Weaknesses (2004).

104. See id. at 32-36.

Thinkers prefer "logical analysis, principles and impersonal reasoning and cost/benefit analyses" and are "more tolerant of conflict and criticism" ... [while] [f] eelers prefer "harmonizing, building relationships, 
ulation, ${ }^{105}$ a majority of lawyers are introverts rather than extroverts; ${ }^{106}$ intuitors rather than sensors; ${ }^{107}$ and judgers rather than perceivers. ${ }^{108}$ Based on her analysis, Daicoff contends that the "definable lawyer personality" is one

conceptually coalesced into two groups of five traits: (a) a drive to achieve ... ; (b) dominance, aggression, competitiveness, and masculinity; (c) emphasis on rights and obligations over emotions, interpersonal harmony, and relationships; (d) materialistic, pragmatic values over altruistic goals; and (e) higher than normal psychological distress. ${ }^{109}$

However, a 2014 empirical study by Margaret Kern and Daniel Bowling casts doubt on whether there are personality traits inherent within those in and choosing to enter the legal profession. Challenging the notion that there is some inherent "lawyer personality," 110 they recognize that early studies support the vicious cycle of lawyers' success coming from pessimism, which leads to unhappiness in life, but note that those studies have not been replicated. ${ }^{111}$ Their study revisited lawyer personalities by assessing twenty-four positive characteristics from the Values in Action Classification of Character Strengths (VIA-IS), because the selected traits "were seen as relatively universal, fulfilling to the individual, morally valued by individuals and societies, trait-like, distinctive, and measurable."112 The study measured the strengths of nearly 300 law students against a sample of U.S. lawyers and six samples of non-lawyers. ${ }^{113}$ They found that the

pleasing people, making decisions on the basis of [their own] . . personal likes and dislikes, and being attentive to the personal needs of Id. at 33 . others" and like to avoid conflict and criticism.

105. Id. at 32-36; see also id. at 34 tbl.2.1.

106. Id. at 32-33. Introverts are those who "focus on their inner world and [who] often feel drained if they spend too much time with other people," whereas extroverts are those who "focus on the outer world and feel energized by contacts with other people." Id.

107. Id. at 33. Intuitors are those who "would rather think about the big picture, abstract ideas, and global themes, learn new things, and solve complex problems," whereas sensors are those who "attend to concrete, real world things and enjoy working with real facts and details." Id.

108. Id. at 32-36; see also id. at 34 tbl.2.1. Judgers are those who "prefer structure, schedules, closure on decisions, planning, follow through, and a "cut-to-thechase' approach," whereas perceivers are those who "prefer a 'go with the flow and see what develops' approach." Id.

109. Id. at $41 \&$ exh. 2.1.

110. Kern \& Bowling, supra note 91, at 29.

111. Id. at 25 (citing, inter alia, Seligman et al., supra note 13).

112. Id. These characteristics are: "appreciation of beauty, authenticity, bravery, creativity, curiosity, fairness, forgiveness, gratitude, hope, humor, kindness, leadership, capacity for love, love of learning, modesty, open-mindedness, persistence, perspective, prudence, self-regulation, social intelligence, spirituality, teamwork, and zest." Id.

113. Id. at $26-27$ tbl.1. 
law students surveyed "demonstrated a normal range of characteristics, similar to other intelligent, highly educated samples."114 Consequently, they conclude "that the supposed presence of a negative "lawyer personality' might be overstated." 115

If it is true that there is no such "negative "lawyer personality" "116_ that it is untrue that "lawyers are ... unhappy people [who] somehow selfselect their own unhappiness by subconsciously placing themselves in a depressing profession," but rather it is "the legal profession [that] makes lawyers unhappy"117 - a question remains whether and to what extent law school and the profession itself contributes to lawyer distress. These are discussed in turn below.

\section{B. Law School}

A significant, decades-long body of scholarship demonstrates that law school poisons the well of prospective lawyers' well-being. For instance, in a 1986 empirical study of law students in Arizona, Andrew Benjamin and his colleagues found that law students were as psychologically healthy as the general population when they enter law school, but within six months "average scores on all symptom indices changed from initial values within the normal range to scores two standard deviations above normative expectation."118 These elevated symptoms "significantly worsened" throughout law school, and they "did not lessen significantly between the spring of third year and the next two years of legal practice." 119 They found that, depending on the group, $17 \%-40 \%$ of the student-subjects "suffered significant levels of depression," with $20 \%-40 \%$ reporting "other significantly elevated symptoms, including obsessive-compulsive, interpersonal sensitivity, anxiety, hostility, paranoid ideation, and psychoticism (social alienation and isolation)." 120 These elevated symptoms were not dependent on

114. Id. at 28 .

115. Id. at 29; see also Krieger \& Sheldon, What Makes Lawyers Happy?, supra note 13, at 621 ("Simply stated, there is nothing ... to suggest that attorneys differ from other people with regard to their prerequisites for feeling good and feeling satisfied with life. ... In order to thrive, we need the same authenticity, autonomy, close relationships, supportive teaching and supervision, altruistic values, and focus on self-understanding and growth that promotes thriving in others.").

116. Kern \& Bowling, supra note 91, at 29. Daicoff argues that "evidence suggests that humanistic, people-oriented individuals do not fare well, psychologically or academically, in law school or in the legal profession." Daicoff, supra note 94, at 1405. However, evidence exists to the contrary-i.e., that students and lawyers who rely on their strengths and act according to their own intrinsic motivations and values perform better and are less distressed. See, e.g., Krieger \& Sheldon, What Makes Lawyers Happy?, supra note 13, at 576-85; Peterson \& Peterson, supra note 101, at 412-16; Kennon M. Sheldon \& Lawrence S. Krieger, Does Legal Education Have Undermining Effects on Law Students? Evaluating Changes in Motivation, Values, and Well-Being, 22 Behavioral Sci. \& L. 261, 281 (2004) [hereinafter Sheldon \& Krieger, Undermining Effects].

117. Litowitz, supra note 57, at 19.

118. Benjamin et al., The Role of Legal Education, supra note 26, at 240.

119. Id. at 241.

120. Id. at 236 . 
Reich: Capitalizing on Healthy Lawyers: The Business Case for Law Firms

any demographic or descriptive differences, including undergraduate or law school GPA; hours devoted to undergraduate or law school studies or to work after graduation; bar examination passage; or size of law practice. $^{121}$

In the mid-2000s, Lawrence Krieger and Kennon Sheldon authored two influential studies of the negative effect law school has on the subjective well-being of law students. ${ }^{122}$ Krieger and Sheldon based their research on the "self-determination theory of optimal motivation and human thriving," or "SDT," which "focuses on the contextual and personality factors that cause positive and negative motivation, with corresponding positive and negative performance and subjective well-being (SWB) outcomes."123 As Krieger and Sheldon describe elsewhere, there are essentially three central tenets of SDT relevant here. First is "that all human beings have certain basic psychological needs-to feel competent/effective, autonomous/authentic, and related/connected with others"; these experiences produce well-being, while their absence correlates to distress. ${ }^{124}$ Second, SDT posits that an individual's "values, goals, and motivations" form the basis of their behavior, and "intrinsic values and internal motivations are more predictive of well-being than their extrinsic and external counterparts." ${ }^{25}$ Finally, SDT posits that supervisors, teachers or

121. Id. at 246 .

122. Sheldon \& Krieger, Undermining Effects, supra note 116; Kennon M. Sheldon \& Lawrence S. Krieger, Understanding the Negative Effects of Legal Education on Law Students: A Longitudinal Test of Self-Determination Theory, 33 Personality \& Soc. Psychol. Bull. 883 (2007) [hereinafter Sheldon \& Krieger, Longitudinal Test of Self-Determination Theory]. Elsewhere, Krieger and Sheldon define "subjective wellbeing" as "the sum of life satisfaction and positive affect, or mood (after subtracting negative affect), utilizing established instruments for each factor." Krieger \& Sheldon, What Makes Lawyers Happy?, supra note 13, at 562. They continue:

These affect and satisfaction factors provide data on complementary aspects of personal experience. Although moods are experienced as transient, they have been found to persist over time in stable ways. Positive and negative affect are purely subjective, straightforward experiences of "feeling good" or "feeling bad" that many people would interpret as happiness or its opposite. Life satisfaction, on the other hand, includes a personal (subjective) evaluation of objective circumstances-such as one's work, home, relationships, possessions, income, and leisure opportunities. Th[is] measure of life satisfaction . . . is validated by its use in previous social science research and is broader than the concept of career or job satisfaction . . . .

Id. at 562-63.

123. Sheldon \& Krieger, Undermining Effects, supra note 116, at 263.

124. Krieger \& Sheldon, What Makes Lawyers Happy?, supra note 13, at 564.

125. Id. at 564-65. As Krieger and Sheldon explain "[v]alues or goals such as personal growth, love, helping others, and building community are considered "intrinsic,' while 'extrinsic' values include affluence, beauty, status, and power." Id. at 564. Additionally, "motivation for behavior is distinguished based on the locus of its source, either 'internal' (the behavior is inherently interesting and enjoyable, or it is meaningful because it furthers one's own values) or 'external' (behavior is compelled by guilt, fear, or pressure, or chosen to please or impress others)." Id. at 564-65. 
mentors who provide "autonomy support" to their subordinates "enhance[] their [subordinates'] ability to perform maximally, fulfill their psychological needs, and experience well-being." ${ }^{26}$ Put simply, SDT research posits that: (1) why a person acts-i.e., for internal satisfaction or external factors; (2) what a person seeks through their actions-i.e., intrinsic goals such as personal growth and community or extrinsic goals such as fame and money; and (3) the level of autonomy support one has from their superiors, all have "significant consequences for [their] satisfaction and performance," as well as their overall SWB. ${ }^{127}$

In their first study, Krieger and Sheldon found that law students enter law school with a higher positive SWB compared with undergraduates. ${ }^{128}$ Yet, one year into law school, students suffered a decline in SWB and an increase in physical and mental health problems. ${ }^{129}$ These declines in well-being and increases in health problems continued throughout law school. ${ }^{130}$

In particular, they found that these increases in mental and physical distress corresponded with decreases in positive affect and overall life satisfaction. ${ }^{131}$ They found further that these increases in distress also corresponded with shifts in their reasons for becoming lawyers-from internal purposes (such as interest and meaning) to external ones (such as money and recognition) ${ }^{132}$-as well as decreases in values of all kinds after the first year. ${ }^{133}$

Krieger and Sheldon conclude that students' "endorsement of intrinsic values" declined over the first year, with a shift toward the extrinsic "appearance and image values." ${ }^{34}$ Additionally, students' goals and motivations moved from the internal- "reasons of interest and enjoyment"to the external, notably "pleasing or impressing others."135 Strikingly, Krieger and Sheldon also found that this shift was not limited to the first year, as "neither the losses in SWB nor in relative intrinsic value orienta-

126. Id. at 565. Krieger and Sheldon describe "autonomy support" as when authorities or superiors "support and acknowledge their subordinates' initiative and self-directness." Sheldon \& Krieger, Longitudinal Test of Self-Determination Theory, supra note 122 , at 884 . When they do so, "those subordinates discover, retain, and enhance their intrinsic motivations and at least internalize nonenjoyable but important extrinsic motivations. In contrast, when authorities are controlling or deny self-agency of subordinates, intrinsic motivations are undermined and internalization is forestalled." Id.

127. Sheldon \& Krieger, Undermining Effects, supra note 116, at 264; Krieger \& Sheldon, What Makes Lawyers Happy?, supra note 13, at 565.

128. Sheldon \& Krieger, Undermining Effects, supra note 116, at 271.

129. Id. at 272 .

130. Id. at 280 .

131. Id. at $270-72$.

132. Id. at 272 tbl.3.

133. Id. at 273 .

134. Id. at 281 .

135. Id. 
tion rebounded" during law school;136 in fact, during the second and third years of law school, all types of valuing decreased. ${ }^{137}$

Krieger and Sheldon did find, however, that students who acted "for intrinsic and self-determined reasons" tended to "perform more persistently, flexibly, creatively, and effectively," and therefore attained a higher GPA. ${ }^{138}$ However, they note the "potential irony" to this finding, because although such students with intrinsic motivations and values performed well academically, such high-performing students "tended to shift toward more lucrative, high-prestige career preferences." 139 And, as discussed below, ${ }^{140}$ the values associated with these positions "tend to contribute to decreased health, SWB, and career satisfaction over time."141

In a 2007 study, Krieger and Sheldon further investigated the negative effects of law school on students' SWB. ${ }^{142}$ It adds to the first study by examining the more nuanced components of SDT-the level of satisfaction of the students' psychological needs for autonomy, competence, and relatedness to others ${ }^{143}$ —as well as the autonomy support students receive from faculty at two different schools, one whose faculty has a "traditional," scholarly focus, and one whose faculty is "less traditional" and focused more on teaching and practical skills for students. ${ }^{144}$ As is relevant here, the study confirmed the findings of their first study, particularly that students' SWB and internal motivation decreased and their distress increased throughout law school. ${ }^{145}$ In particular, they found that these negative outcomes resulted from decreases in students' satisfaction in their needs for autonomy, competence, and relatedness since entering law school. ${ }^{146}$

Thus, these studies, among others, ${ }^{147}$ have demonstrated that law students suffer disproportionately high levels of distress and suggest that this

136. Id

137. Id. at 282. Krieger and Sheldon observe that this finding is "consistent with the common stereotype that lawyers 'have no values' - that they are hired guns willing to represent any position that promises to pay." Id.

138. Id. at 281; cf. Peterson \& Peterson, supra note 101, at 411 (reporting results of survey of George Washington University Law School students that revealed "students who use their strengths on a regular basis report higher satisfaction with life and lower levels of stress and depression.").

139. Sheldon \& Krieger, Undermining Effects, supra note 116, at 281.

140. See infra Section II.C.

141. Sheldon \& Krieger, Undermining Effects, supra note 116, at 281.

142. Sheldon \& Krieger, Longitudinal Test of Self-Determination Theory, supra note 122 .

143. Id. at $886-87$.

144. Id.

145. Id. at 889 .

146. See id. at 893-94. Additionally, students at the law school with the "less traditional" faculty reported a more autonomy-supportive environment and fared better in all other measured outcomes-well-being, grade performance, and career motivation-than students at the school with the "traditional," and less autonomy-supportive, faculty. Id. at 890-91 \& tbls.2 \& 3.

147. See, e.g., Am. Ass'n of Law Schools, supra note 48; Jessie Agatstein et al., Falling Through the Cracks: A Report on Mental Health at Yale Law 
distress correlates to law school itself. These elevated levels of mental health and addiction issues among law students remain high today. In 2014, Jerome Organ, David Jaffe, and Katherine Bender surveyed more than 3,300 students across fifteen law schools to assess mental health and substance abuse issues among students as well as whether and to what extent students seek help for these issues. ${ }^{148}$ They found that $17 \%$ of respondents screened positive for depression, ${ }^{149} 37 \%$ screened positive for anxiety, ${ }^{150} 43 \%$ reported binge-drinking at least once in the prior two weeks, ${ }^{151} 25 \%$ were at risk for alcoholism, ${ }^{152}$ and $35 \%$ used illicit street drugs or prescription drugs without a prescription. ${ }^{153}$ Additionally, a 2014 non-empirically validated survey of students at Yale Law School found that up to $70 \%$ of its students suffer from some form of self-identified mental distress while in school. ${ }^{154}$

The reasons why law school causes such declines in well-being and rises in mental health and substance abuse among its students is beyond the scope of this Article, but suffice it to say that as a result of the law school model, students experience many of the same distress, mental health, and addiction issues that pervade the legal profession, ${ }^{155}$ and it may lay the groundwork for that very pervasiveness. ${ }^{156}$

\section{Law Practice}

In 2015, Krieger and Sheldon conducted an empirical study of nearly 8,000 lawyers throughout the United States across all areas of practice to determine the contributors to lawyer well-being and life satisfaction, as well as distress and dissatisfaction. ${ }^{157}$ In designing their study, they mea-

School (2014), https://law.yale.edu/sites/default/files/area/department/studentaffairs/document/falling_through_the_cracks.pdf [https://perma.cc/38N29B8N]; Mathew M. Dammeyer \& Narina Nunez, Anxiety and Depression Among Law Students: Current Knowledge and Future Directions, 23 L. \& Hum. Behavior 55 (1999); Lawrence Silver, Anxiety and the First Semester of Law School, 1968 Wis. L. Rev. 1201 (1968).

148. Organ et al., supra note 68 , at 122-26. For a discussion of the barriers to treatment, see infra Section II.B.

149. Organ et al., supra note 68, at 136.

150. Id. at $137-38$.

151. Id. at $128-29 \&$ tbl.2.

152. Id. at 131-32 \& tbl.5. Further, the authors noted that "consumption of alcohol among law students appears to have become more prevalent than two decades ago." Id. at 127.

153. Id. at $133-36$.

154. Agatstein et al., supra note 147.

155. See, e.g., Stefancic \& Delgado, supra note 57, at 62-63; see also, e.g., Litowitz, supra note 57, at 29-51 (discussing "the trouble with law school"); Dammeyer \& Nunez, supra note 147, at 61; Peterson \& Peterson, supra note 101, at 358.

156. Debra S. Austin, Killing Them Softly: Neuroscience and Neural Self-Hacking Can Optimize Cognitive Performance, 59 Loy. L. Rev. 791, 793-94 (2013) ("Stress in legal education may ... set the stage for abnormally high rates of anxiety and depression among lawyers.").

157. Krieger \& Sheldon, What Makes Lawyers Happy?, supra note 13. 
sured the SWB metrics (need satisfaction, values, and motivations) as well as depression and alcohol consumption. ${ }^{158}$

Consistent with their prior studies of law students, Krieger and Sheldon found that internal values and motivations-the very factors that erode during law school-and psychological need satisfaction were most strongly predictive of lawyer well-being, whereas "the external factors emphasized in law school and by many legal employers were, at best, only modestly associated with lawyer well-being." 159 The strongest predictors of well-being were the psychological needs of autonomy, relatedness to others, and competence, as well as motivation. ${ }^{160}$ They determined that the correlations between psychological needs and lawyer well-being were "exceptionally strong," and that these needs were strongly inversely correlated with depression ${ }^{161}$ as well as inversely correlated with quantity of drinking. ${ }^{162}$

Accordingly, aspects of the profession that inhibit these psychological needs, and foster external values and motivations, can contribute to lawyer mental health and addiction issues. While a myriad of such aspects certainly exists, three critical areas are: (1) lack of autonomy; (2) lack of relatedness; and (3) extrinsic values and motivation.

\section{Lack of Autonomy}

Autonomy is one of the key metrics for lawyer happiness, ${ }^{163}$ and its absence in "high-pressure, low decision latitude" positions of law firm associates render associates "likely candidates for negative health effects"164 such as depression. ${ }^{165}$ While there are many areas of the profession that engender a lack of autonomy, this Article focuses on two: the reliance on the billable hour as a measure of productivity and compensation and the low decision latitude of particularly junior lawyers.

\section{a. Reliance on the Billable Hour}

The prevailing business model for law firms over the last several decades is the billable hour, by which they charge their clients an hourly rate

158. Id. at 569.

159. Id. at 585; see id. at 583 fig.1, 584-85.

160. Id. at 585. In fact, psychological need satisfaction measured "relationships to well-being approximately . . 3.5 times stronger than that of income." $I d$. at 579 .

161. Id. at 579 .

162. Id. at 586-87.

163. Id. at 582-84 \& figs.1 \& 2; see also Eaton et al., supra note 10, at 1086 (" $[\mathrm{P}]$ eople in occupations that involve individual autonomy, control over the environment, and direction and planning of the flow of work will be protected against depression.")

164. Seligman et al., supra note 13 , at 42.

165. Eaton et al., supra note 10, at 1086 ("Occupations involving little or no direction or control contribute to a relatively stable personality configuration linked to learned helplessness, which has been implicated in depression."). 
for each hour each lawyer works. As law firms have commodified over the last thirty-five years, ${ }^{166}$ hour expectations have increased. For instance, in the early 1980s, few law firms had minimum billable hour requirements, but in recent years "most large law firms expressly set them at 1,900 to $2,000, " 167$ with some firms expecting much more. ${ }^{168}$

Billable hours as a benchmark of productivity is counterintuitive, as "the behavior that maximizes hours is antithetical to true productivity." 169 While "[p] roductivity [generally] is the "relative measure of the efficiency of a person ... . in converting inputs into useful outputs," the general benchmark of lawyer productivity-the total time spent on a task without regard to the quality or utility of the work product-is a measure of anything but productivity. ${ }^{170}$ Indeed, more hours spent on a task is an indication of unproductivity, as workers are less productive and efficient the longer they toil on a task. ${ }^{171}$ Put differently, the billable hour system rewards unproductivity and inefficiency.

Notwithstanding this inherent inefficiency, billable hours are the standard measure of work, and law firm associates understand that their futures depend on this measure of output, and their success at the firm requires them to bill much more than the firm's stated billable hour target. ${ }^{172}$ Moreover, a lawyer must "work" many more hours to hit their billable target. ${ }^{173}$ For instance, Yale Law School calculated that a lawyer must

166. See generally HARPER, supra note 20. Although billable hours can bear on autonomy and relatedness satisfaction (as well as motivation), see Krieger \& Sheldon, supra note 13 , at 596, but is included as related to "competence" because it rewards inefficiency. Cf. Deborah L. Rhode, The Trouble with Lawyers 13 (2015) (" $[\mathrm{T}]$ he hourly billing system pegs profits more to the quantity of time spent than to the efficiency of its use, and profits have become the dominant concern. High billable hour quotas also screen out individuals with competing values. A willingness to work long hours functions as a proxy for commitment.").

167. HARPER, supra note 20, at 79; Update on Associate Hours Worked, NALP Bull. (2016), https://www.nalp.org/0516research [https://perma.cc/7499TKEQ] (reporting that nearly $60 \%$ of law firms require that lawyers bill at least 1,900 hours). But see Citr. for the Study of the Legal Profession, Georgetown Law \& Legal Exec. Inst., 2019 Report on the State of the Legal Market 7 fig.8 (2019), http://ask.legalsolutions.thomsonreuters.info/LEI_2019-State_of_Legal_ Mkt [https://perma.cc/MDQ6-V9F8] (reporting that the average lawyer at $16 \overline{1}$ U.S.-based law firms surveyed billed 122 hours per month in 2018, or 1,464 hours per year).

168. See, e.g., Ingo Forstenlechner \& Fiona Lettice, Well Paid but Undervalued and Overworked: The Highs and Lows of Being a Junior Lawyer in a Leading Law Firm, 30 EMP. REL. 640, 642 (2008) (noting that although the international law firm studied had no official billable hour target, "there [was] an unofficial target of 2,400 hours").

169. HARPER, supra note 20, at 77.

170. Id. at 78-79.

171. Id. (noting the effort spent "on the fourteenth hour of a day can't be as valuable as that exerted during hour six").

172. Id. at 79 .

173. See, e.g., DLA Piper LLP-U.S. Firmwide: Hours and Work Arrangements, NALP Directory of LeGAL EMP'Rs (2019), http://nalpdirectory.com/employer_profile? FormID $=11656 \&$ QuestionTabID $=39 \&$ SearchCondJSSe $=\% 7 \mathrm{~B} \%$ 22SearchEmployer 
Reich: Capitalizing on Healthy Lawyers: The Business Case for Law Firms

be at work 2,420 hours to bill 1,800, and that 2,200 billable hours requires an lawyer be "at work" 3,048 hours. ${ }^{174}$

It is no wonder, then, as the ABA's Commission on Women in the Profession warned nearly twenty years ago, that "[e]xcessive workloads are a leading cause of lawyers' disproportionately high rates of reproductive dysfunction, stress, substance abuse, and mental health difficulties."175 As one lawyer put it, billable hours are "the biggest reason lawyers are so depressed." 176

\section{b. Low Decision Latitude}

Beyond the number of hours worked, many lawyers-particularly junior lawyers ${ }^{177}$ _experience distress because they lack autonomy in the work that they do. Associates have little say over their work, limited inter-

Name\%22\%3A\%22dla\%20piper\%22\%7D [https://perma.cc/TTJ9-ZNM5] (last visited May 7, 2020) (noting that, on average, associates firm-wide in 2018 billed 1,860 hours yet worked 2,343).

174. The Truth About the Billable Hour, YALE L. Sch. (July 2017), https:// law.yale.edu/sites/default/files/area/department/cdo/document/billable_hour.pdf [https://perma.cc/ZF2E-2LWF]; see also Colin James, Legal Practice on Time: The Ethical Risk and Inefficiency of the Six-Minute Unit, 42 Alt. L.J. 61, 62 (2017) (finding, that for Australian solicitors, "time-billing may record 50 to 70 per cent of the actual hours worked").

175. Deborah L. Rhode, Am. Bar Ass'n, Comm'n on Women in the Profession, Balanced Lives: Changing the Culture of Legal Practice 12 (2001); cf. Debra Austin \& Rob Durr, Emotion Regulation for Lawyers: A Mind Is a Challenging Thing to Tame, 16 Wyo. L. Rev. 387, 401 (2016) ("A lawyer subjected to chronic stress can experience emotional disorders such as anxiety, panic attacks, or depression, and physical problems such as irritability, breathlessness, dizziness, abdominal discomfort, muscle tension, sweating, chills, heart palpitations, chest pain, and/or increased blood pressure.").

176. Joshua E. Perry, The Ethical Costs of Commercializing the Professions: FirstPerson Narratives from the Legal and Medical Trenches, 13 Penn. J.L. \& Soc. Change 169, 184 n.57 (2009). But see Krieger \& Sheldon, What Makes Lawyers Happy?, supra note 13, at 596 (finding that while "important psychological predictors of wellbeing decreased" with increased billable hours, such increases only led to "slightly less happiness"); Bergin \& Jimmieson, supra note 63, at 437 (finding that high billing lawyers "experienced greater anxiety, more stress, more job dissatisfaction and less work/life balance," but that their study "did not provide evidence that having high billing targets was related to greater levels of depression and drinking, compared with lawyers with low-to-moderate billing targets or no billing targets").

177. However, despite their higher status and $62 \%$ greater pay than senior associates, junior partners "experience[] no greater happiness than the associates." Krieger \& Sheldon, What Makes Lawyers Happy?, supra note 13, at 597-98; cf. Jonathan Koltai et al., The Status-Health Paradox: Organizational Context, Stress Exposure, and Well-Being in the Legal Profession, 59 J. Health \& Soc. Behavior 20, 31 (2018) (finding that "higher status lawyers have a mental health disadvantage relative to their peers in the public sector, and are no better off in terms of health"). In the words of one law firm partner: "[T] he hours don't get any better for partners; partners have even more pressure than associates do." Kimberly Kirkland, Ethics in Large Law Firms: The Principles of Pragmatism, 35 U. Mem. L. Rev. 631, 683 (2005). 
action with senior partners, and little to no client contact. ${ }^{178}$ With this lack of autonomy also comes isolation, as firms have "little mentoring, training, or firm citizenship behaviors," and there is little institutional incentive to engage in them. ${ }^{179}$ Consequently, lawyers feel alienated from their work and cannot see how it matters beyond being a billable deliverable. ${ }^{180}$ As an illustration, in one survey of associates at an international law firm, approximately $86 \%$ said they have non-interesting work, approximately $88 \%$ said they do not have interaction with partners, and approximately $77 \%$ said they are not "being shown appreciation for their work" by senior associates or partners. ${ }^{181}$

Junior lawyers have expressed "angst over pressures to bill exorbitant amounts of money to clients to whom they felt no meaningful connection."182 They also have expressed frustration over the conflict between "their presumed role as autonomous professionals who" establish and maintain client relationships "and their more subservient role as employees who" exist to generate partner revenue. ${ }^{183}$

Additionally, with advances in technology, lawyers are increasingly ondemand around the clock. Lawyers are expected to be reachable at all times, and in effect are constantly on call. ${ }^{184}$ With this, lawyers have less autonomy support-that is, superiors do not acknowledge the lawyers' perspective or preferences, or provide them with meaningful choices about when and where to work and how to balance their lives. While technology makes it possible for lawyers to work from home, it also makes it virtually impossible not to work from home; consequently, "[p] ersonal lives get lost in the shuffle." 185 This "effective monitoring" of lawyer work at all times is true not only of junior lawyers, but also for senior lawyers who fear losing clients for being unresponsive on demand. ${ }^{186}$

178. Seligman et al., supra note 13 , at 42.

179. Anne M. Brafford, Building a Positive Law Firm: The Legal Profession at Its Best 13 (Apr. 1, 2014) (unpublished Master of Applied Positive Psychology (MAPP) thesis, University of Pennsylvania), https://repository.upenn.edu/cgi/ viewcontent.cgi? article $=1063 \&$ context $=$ mapp_capstone $\quad[$ https: $/ /$ perma.cc $/ 2 T T X-$ L435]; see also Schiltz, supra note 13, at 934-38 (discussing how "the vaunted training of big firms does not exist").

180. Levit \& Linder, supra note 13, at 63 ("Lawyers become alienated from the nature of their work, and they do not see how their work matters.").

181. Forstenlechner \& Lettice, supra note 168, at 647 \& tbl.v.

182. Perry, supra note 176 , at 198.

183. Id.

184. Forstenlechner \& Lettice, supra note 168, at 643; see also RHODE, supra note 166, at 13 ("In some ways, technology has made a bad situation worse by accelerating the pace of practice and placing lawyers perpetually on call.”).

185. RHode, supra note 166 , at 13.

186. Forstenlechner \& Lettice, supra note 168, at 643; see also RHODE, supra note 166, at 13 ("It is not uncommon to hear of a client who e-mails on New Year's Eve and fires a firm for being insufficiently responsive on a Sunday morning."); Caroline Spiezio, Constantly on Call: The Client's Role in the Legal Profession's Mental Health Crisis, Corp. Coun. (July 14, 2019), https://www.law.com/corpcounsel/20 $19 / 07 / 14 /$ constantly-on-call-the-clients-role-in-the-legal-professions-mental-health- 


\section{Lack of Relatedness: Adversarial System}

The practice of law is inherently adversarial, which itself is inherently stressful by nature. ${ }^{187}$ To thrive in the adversarial system, lawyers are trained to be competitive and aggressive because the goal is to "win." 188 Such training is "fueled by negative emotions," and as a consequence "can be a source of lawyer demoralization, even if it fulfills a social function." 189 Consequently, when the practice of law is reduced to many zero-sum disputes, it can "produce predictable emotional consequences for the practitioner, who will be anxious, angry, and sad much of [their] professional life."190 Moreover, dealing with difficult opponents, clients, and colleagues can often leave lawyers feeling "emotionally shattered."191

\section{Extrinsic Values and Motivations}

Lawyers often enter a firm culture "that is hostile to [their] values." 192 As Judge (then-Professor) Patrick Schiltz observed:

The system does not want you to apply the same values in the workplace that you do outside of work . . . ; it wants you to replace those values with the system's values. The system is obsessed with money, and it wants you to be, too. The system wants you-it needs you—to play the game. ${ }^{193}$

As a result of this "game," law is no longer seen by many as a calling, ${ }^{194}$ but as "just a job with ridiculous hours, stress, and unpaid law

crisis/ [https://perma.cc/5S9D-PSVR] ("Client demands for fast turnaround times, even on non-urgent matters, can leave outside counsel in constant crisis mode. That stress can lead to ... mental health issues such as depression, addiction, and anxiety ....").

187. Krieger \& Sheldon, What Makes Lawyers Happy?, supra note 13, at 599.

188. See Seligman et al., supra note 13, at 47. A recent study of American and Canadian lawyers revealed that lawyers at large firms experience higher rates of "depressive symptoms and risk of poor health" than those in smaller firms or the public sector, including because such lawyers have "higher levels of overwork" and work-life conflict. Koltai et al., supra note 177, at 31-32.

189. Seligman et al., supra note 13 , at 47 .

190. Id.

191. Angus Lyon, Lawyer's Guide to Wellbeing and Managing Stress 97 (2015).

192. Schiltz, supra note 13 , at 912.

193. Id.

194. There are essentially three different mindsets people have about their work: jobs, careers, and callings. See, e.g., Amy Wrzesniewski et al., Jobs, Careers, and Callings: People's Relations to Their Work, 31 J. Res. Personality 21, 22 (1997). Briefly, a job "is a means that allows individuals to acquire the resources needed to enjoy their time away from" it. Id. A career is a position in which one has "a deeper personal investment in their work and mark their achievements not only though monetary gain, but through advancement within the occupational structure," which "often brings higher social standing, increased power within the scope of one's occupation, and higher self-esteem for the worker." Id. A calling is a position one "works not for financial gain or [c] areer advancement, but instead for the 
school debt," 195 and a primary focus on generating revenue for the firm. This "loss of purpose beyond making money" contributes greatly to lawyer dissatisfaction, ${ }^{196}$ and it should come as no surprise that along with wellbeing, lawyers believe legal professionalism is in decline as well. ${ }^{197}$ As a consequence, there has been a call for a return to more traditional notions of law practice, ones that prioritizes integrity, civility, and community. ${ }^{198}$ More generally, if lawyers "re-discover why they became lawyers in the first place and rededicate themselves to those intrinsic goals" and motivations that initially led them to law school, it will lead to a "happier, healthier, and more ethical profession." 199

\section{Ignoring the Moral Case for Lawyer Well-Being}

Notwithstanding the existence and the profession's knowledge of the widespread prevalence of lawyer mental health and addiction issues, as well as some obvious costs associated with them, law firms (and the profession at large) have ignored the pleas for change. These pleas, largely resting on moral grounds, have gone unheeded largely for two reasons: (1) firms have cared primarily about their bottom lines; and (2) the stigma associated with mental health and addiction issues, as well as other barri-

fulfillment that doing the work brings for the individual." $I d$. Individuals who view their work as callings generally have "greater life, health, and job satisfaction and ... better health" than those who view their work as mere jobs or careers. See id. at 29, 30-31; see also id. at 27 tbl.3. A person can find their calling within any occupation. See id. at 22; $c f$. id. at 31 (finding each mindset represented in nearly equal thirds among sample administrative assistants, concluding that "[s]atisfaction with life and with work may be more dependent on how an employee sees his or her work than on income or occupational prestige").

195. Daniel S. Bowling, III, Lawyers and Their Elusive Pursuit of Happiness: Does It Matter?, 7 Duke F. L. \& Soc. Change 37, 49 (2015) (footnotes omitted).

196. Barry Schwartz \& Kenneth Sharpe, Practical Wisdom: The Right Way to Do the Right Thing 216-17 (2010). Moreover, increased compensation does not contribute to lawyer subjective well-being. See Krieger \& Sheldon, What Makes Lawyers Happy?, supra note 13, at 583 fig.1, 597-98. In fact, public interest lawyers responding to Krieger and Sheldon's survey reported greater subjective well-being than their highly-paid "elite" and "prestige" lawyers at private firms. Id. at 590-91, 593 tbl.1.

197. Bowling, supra note 195, at 48; see also Krieger \& Sheldon, What Makes Lawyers Happy?, supra note 13, at 612 (noting that survey respondents "has a positive view of neither the justice in the justice system nor the professional behavior of professionals in the system").

198. Susan Daicoff, Asking Lawyers to Change Their Spots: Should Lawyers Change? A Critique of Solutions to Problems with Professionalism by Reference to Empirically-Derived Attorney Personality Attributes, 11 Geo. J. Legal Ethics 547, 582 (1998) (noting the call for a "return to more traditional, gentlemanly law practice," in which lawyers "abandon these [financial and competitive] motivations and instead adopt a moral system that values integrity, honesty, community service, pro bono work, courteousness, civility, cooperation with others, and sensitivity to interpersonal concerns").

199. Bowling, supra note 195 , at 49-50. 
ers to treatment. As set forth below, each inhibits, undermines, and puts at risk, lawyer well-being.

\section{A. The Profit-Centered Practice: Commodification of Law Firms}

Over the past thirty-plus years, firms have moved from the idea of the "noble profession" and toward the profit-maximizing "business model" dominating private practice today. ${ }^{200}$ As a result of the American Lawyer first publishing its annual list of firms' revenues and profits-per-partner in 1985, lawyers were able to discover how much their colleagues were making elsewhere, and earning a high spot on the "Am Law 100," or firms with the top 100 revenues nationwide, was a coveted honor. ${ }^{201}$ In response, firms adopted management techniques aimed at moving them up in the annual rankings. ${ }^{202}$ As a consequence, total gross revenue for Am Law 100 firms has gone from $\$ 7$ billion in 1985 to $\$ 71$ billion in 2010 - a $9.71 \%$ compound annual growth rate 203 — to $\$ 98.75$ billion in 2018.204

Moreover, "[m]anaging partners admit publicly that they run their firms to maximize instant profits for the relatively few"-the partners. ${ }^{205}$ And, to that end, their practices have been successful: while in 1985 the average profits-per-partner for the top fifty firms on AmLaw's inaugural list was $\$ 300,000$, that figure for the top fifty firms in the Am Law 100 in 2011 had risen to $\$ 1.6$ million,"206 and to $\$ 2.54$ million in $2018 .^{207}$

Partner profits are maximized through the so-called "Cravath model," 208 which focuses on high leverage, high hourly rates, and high billable hours. ${ }^{209}$ Taking each in turn, first, a firm's leverage refers to the ratio of its salaried lawyers (i.e., associates, counsel, and non-equity partners) to equity partners. ${ }^{210}$ The higher the leverage, the more money the firm's equity partners make. ${ }^{211}$ To achieve higher leverage, firms hire

200. HARPER, supra note 20 , at 70 .

201. Id. at 72 .

202. $I d$.

203. Bruce MacEwen, Growth Is Dead: Now What? Law Firms on the BRINK 15 (2013).

204. The Am Law 100 2019, Am. Law. (May 2019).

205. HARPER, supra note 20, at 76 .

206. Id. at 72 .

207. The Am Law 100 2019, supra note 204. Average profits-per-partner was calculated using data listed for the top fifty firms by total revenue.

208. Under the "Cravath model," firms "hire a large number of associates . . so that only the most brilliant legal minds ascended to its partnership. (Historically, about one in twelve associates make partner.)... . [Meanwhile,] the firm ma[kes] a killing by billing [associates] out at top-of-the-market rates." Noam Scheiber, The Last Days of Big Law: You Can't Imagine the Terror When the Money Dries Up, New Republic, https://newrepublic.com/article/113941/big-law-firmstrouble-when-money-dries [https://perma.cc/TC96-P5BA].

209. See HARPer, supra note 20, at 76-79. Harper refers to leverage, hourly rates, and billable hours as a "three-legged stool." See id.

210. Id. at 77 .

211. Id. 
many more associates than they expect will be promoted to equity partnership (or even remain with the firm beyond a few years). ${ }^{212}$ Put simply, it is in firms' interest to hire many associates with the expectation to make few, if any, partner, because more associates means more profits for partners, and fewer partners means a larger share for each. ${ }^{213}$ This practice has yielded considerable results. Since the creation of the Am Law 100, leverage ratios have grown considerably: in 1985, the average leverage ratio for the top fifty Am Law-ranked firms was 1.76; it doubled to 3.54 in 2010, ${ }^{214}$ and it rose to 4.47 in $2018,{ }^{215}$ with, as noted above, the average profits per equity partner at $\$ 2.54$ million. ${ }^{216}$

Second, firms' hourly rates have risen steadily both before and after the Great Recession of the late 2000s, with many firms raising their billing rates by $5 \%$ annually after the recession, and the top twelve firms raising rates more than 7\%.217 Finally, the third component of the Cravath model is high billable hour expectations. As discussed in Section II.C.1.a above, as law firms have commodified over the last thirty-five years, hour expectations have increased from no minimum billable hour requirements in the early 1980 s to at or above 2,000 hours today. ${ }^{218}$

Thus, as a result of the Cravath model, a firm achieves its successi.e., maximizing revenue and profits per partner-by hiring large classes of associates each year and requiring them to work long hours for the years preceding their eligibility for partnership. ${ }^{219}$ This model not only keeps equity partner wealth growing by the continuous influx of new junior associates but also leads to significant attrition such that few associates last long enough even to be considered for equity partner. ${ }^{220}$ As firms have adopted the Cravath model, they have reinvented themselves as profit-generating businesses by which only a few partners at the top truly benefit. ${ }^{221}$

Even though firms produce considerable revenue, partners are not content with their existing wealth; they think they should be making more

212. Id.

213. Schiltz, supra note 13, at 901 (citing Ronald J. Gilson \& Robert H. Mnookin, Coming of Age in a Corporate Law Firm: The Economics of Associate Career Patterns, 41 Stan. L. Rev. 567, 584 (1989)).

214. HARPER, supra note 20, at 82.

215. Am Law 100 2019, supra note 204 (average leverage ratio of top fifty firms by total revenue).

216. Id.

217. Harper, supra note 20, at 77.

218. See supra notes 166-168 and accompanying text.

219. HARPer, supra note 20, at 85-86; cf. id. at 90 (noting that the Cravath model "create[s] conditions that decrease opportunities for advancement and are hostile to any attorney's search for a balanced life").

220. Id.

221. Id. 
money. ${ }^{222}$ Consequently, firms' short-run focus on the maximization of annual profits has also become their "most important long-run goal."223

As partner profits and firm revenue have increased so too has lawyer distress and dissatisfaction. While firms and their equity partners have achieved staggering wealth, it has come at considerable costs as lawyer mental health and addiction issues have become pervasive. ${ }^{224}$ The added income (as well as the client expectations arising from higher billing rates) brings an assumed obligation to work longer hours, often at the expense of lawyers' health and personal lives. ${ }^{225}$ In other words, as set out in Section II.C above, law firms in general are undermining their lawyers' internal values and motivations that foster subjective well-being in favor of prioritizing the external values and motivations that correlate to emotional distress. ${ }^{226}$

It is likely that a "disturbingly large number" of Big Law lawyers would acknowledge that their exorbitant salaries have not brought them happiness. ${ }^{227}$ In fact, some likely would be willing to take less salary if it meant a more balanced life. ${ }^{228}$

Since money-profit generation and maximization-is at the heart of much of the distress and dissatisfaction within the profession, ${ }^{229}$ the answer to addressing such distress and dissatisfaction is not to provide addi-

222. MACEwEN, supra note 203, at 21 ("Partners of all classes and genders [are] united on one front: They all think they should be making more money."). In one survey, "[f]ifty-eight percent of all partners said they should be better paid, and among that group, an overwhelming majority wants something more than a token raise. Ninety percent of the survey's respondents thought that their compensation should be increased by more than 10 percent, while 1 percent thought their pay should be doubled." Id. But see Am. Bar Ass'N Comm'n on Billable Hours, ABA Commission on Billable Hours Report 2001-2002, at ix (2002), http://ilta.personifycloud.com/webfiles/productfiles/914311/FMPG4_ABABill ableHours2002.pdf [https://perma.cc/MQ7D-248D] (finding an increasing number of lawyers would prefer a pay cut to increase quality of life rather than continuing to rely on the billable hour).

223. HARPER, supra note 20, at 96.

224. Id. (" $[\mathrm{P}]$ artner profits and attorney [depression and job] dissatisfaction have risen in tandem as big firms' lawyers make more money and enjoy it less. Those twin developments are not coincidental.").

225. Id. at 97.

226. See supra Section II.C.

227. HARPER, supra note 20, at 97.

228. Id. (arguing lawyers would accept a lower salary because "their work remains a persistently depressing experience, largely because it seems unfulfilling, unrelenting, or both"). But see Schiltz, supra note 13, at 904-05 ("Lawyers could enjoy a lot more life outside of work if they were willing to accept relatively modest reductions in their incomes. . . . But many of them do take the money. [They] choose to give up a healthy, happy, well-balanced life for a less healthy, less happy life dominated by work. And they do so merely to be able to make seven or eight times the national median income instead of five or six times the national income.").

229. See Schiltz, supra note 13, at 903 ("Money is at the root of virtually everything that lawyers don't like about their profession: the long hours, the commercialization, the tremendous pressure to attract and retain clients, the fiercely 
tional financial incentives. ${ }^{230}$ Studies abound demonstrating that money, at a certain level below the median lawyer salary, does not increase happiness. ${ }^{231}$ Nevertheless, firms have done just that: they have responded in recent years to increased lawyer distress, dissatisfaction, and attrition by increasing salaries. This has continued even in the wake of the Krill Study and the ABA's The Path to Lawyer Well-Being: in Summer 2018, many firms began to raise their starting salary for a first-year associate to $\$ 190,000$ (if not higher), with an eighth-year associate's salary far exceeding $\$ 300,000.232$

\section{B. Stigma and Barriers to Treatment}

Although awareness and understanding of mental illness have increased in recent years, it is still not often treated legitimately or seriously "either by businesses, by the health care system, or by our society." ${ }^{233}$ This is true in the legal profession, in which "mental health "is not talked about openly" and, for years, has been kept "underground." 234

competitive marketplace, the lack of collegiality and loyalty among partners, the poor public image of the profession, and even the lack of civility.").

230. Indeed,

[1]ife satisfaction in the United States has been flat for fifty years even though GDP has tripled. Even scarier, measures of ill-being have not declined as gross domestic product has increased; they have gotten much worse. Depression rates have increased tenfold over the last fifty years in the United States. . . . Rates of anxiety have also risen.

Martin E.P. Seligman, Flourish: A Visionary New Understanding of Happiness ANd Well-Being 223 (1st ed. 2011).

231. See Levit \& Linder, supra note 13, at 10-11.

232. Stacy Zaretsky, Salary Wars Scorecard: Which Firms Have Announced Raises and Bonuses, Aвоve L. (June 5, 2018, 1:46 PM), http://abovethelaw.com/2018/ 06/salary-wars-scorecard-which-firms-have-announced-raises-2018/ [https://per ma.cc/TU8X-83XQ]; see also Christine Simmons, Milbank Boosts Associate Salaries with \$190k Starting Pay, Am. Law. (June 4, 2018), http://www,law.com/american lawyer/2018/06/04/milbank-boosts-associate-salaries-with-190k-starting-pay/ [https://perma.cc/HZN2-GLHE].

233. Stewart Friedman, The Hidden Business Cost of Mental Illness, Harv. Bus. Rev. (Dec. 3, 2009), http://hbr.org/2009/12/the-hidden-business-cost-of-me .html\# [https://perma.cc/J24U-59DL].

234. William Roberts, When Counsel Needs Counseling, Wash. Law., Jan. 2018, at 20, http://washingtonlawyer.dcbar.org/january2018/index.php?startid=16\#/p/16 [https://perma.cc/74CM-Z852] (quoting Arent Fox LLP partner David Dubrow); see also Zimmerman, supra note 5 ("'Law firms have a culture of keeping things underground, a conspiracy of silence,' [Dr. Daniel Angres, an associate professor of psychiatry at Northwestern University Feinberg School of Medicine] said. 'There is a desire not to embarrass people, and as long as they are performing, it's easier to just avoid it. And there's a lack of understanding that addiction is a disease." "). In a 2017 New Yorker profile, former Acting Attorney General Sally Yates discussed her father's suicide in 1986, for which she said: “'Tragically, the fear of stigma then associated with depression prevented him from getting the treatment he needed." Ryan Lizza, Why Sally Yates Stood up to Trump, New Yorker (May 29, 2017), http:/ / www.newyorker.com/magazine/2017/05/29/why-sally-yates-stoodup-to-trump [https://perma.cc/35ND-B9X7]. 
The profession recognizes that this stigma exists. A 2018 survey of managing partners and human resources personnel at Am Law 200 law firms revealed that stigma associated with mental illness and substance abuse is prevalent in the profession. ${ }^{235}$ In particular, $81 \%$ of those surveyed believe a stigma exists against those suffering from depression, and $75 \%$ believe a stigma exists against those suffering from anxiety. ${ }^{236}$ The numbers are even starker for those with substance abuse problems, with $94 \%$ of those surveyed believing a stigma exists against both those suffering from alcohol addiction and drug addiction. ${ }^{237}$

The stigma pervades the profession in a variety of ways. First, there is fear that lawyers struggling with mental health or addiction disorders are incompetent, incapable, or undesirable. This is succinctly captured by the comments of the chairman of an Am Law 100 law firm, who expressed reticence to follow other firms in having an on-site psychologist because of the fear that "our competitors will say we have crazy lawyers." 238

Second, the overwhelming majority of state bars ask questions relating to applicants' mental health or substance use. Many states have historically asked bar applicants whether they had any history of mental health treatment. Even after a 2014 Department of Justice settlement with the Louisiana Supreme Court in which the State of Louisiana agreed to remove questions from its bar application about an applicant's mental health history, several states still ask whether applicants have any such history. 239

As of March 2020, out of the fifty states, the District of Columbia, Guam, Northern Mariana Islands, Puerto Rico, and the Virgin Islands, ${ }^{240}$

235. Alm Intelligence, 2018 Mental Health and Substance Abuse Survey (2018).

236. Id.

237. Id. Additionally, the stigma for drug use may be further internalized; in the Krill Study, less than $27 \%$ of participants responded to questions concerning drug use, compared with approximately $90 \%$ for questions relating both to mental health and alcohol use. Krill et al., supra note 10, at 48-50; see also id. at 52 ("Because the questions in the survey asked about intimate issues, including issues that could jeopardize participants' legal careers if asked in other contexts (e.g., illicit drug use), the participants may have withheld information or responded in a way that made them seem more favorable.").

238. Randazzo, supra note 22 (internal quotation marks omitted).

239. See Alyssa Dragnich, Have You Ever . . . ?: How State Bar Association Inquiries into Mental Health Violate the Americans with Disabilities Act, 80 Brook. L. Rev. 677, 677 (2015).

240. Applications are on file with the author; the following information is based on the most recent attainable applications. For additional, summary information about U.S. bar applications, see generally Bar Admission Questions Pertaining to Mental Health, School/Criminal History, and Financial Issues, Judge DAvID L. Bazelon Ctr. Mental Health L., http://bazelon.org/wp-content/uploads/ 2019/12/50-State-Survey-To-Post.pdf [https://perma.cc/N9BF-7BP8] (last updated Feb. 2019); David Jaffe \& Janet Stearns, Conduct Yourselves Accordingly: Amending Bar Character and Fitness Questions to Promote Lawyer Well-Being, 26 Prof. LAw. 3 (2020). 
all but nine jurisdictions ask some question related to the bar applicant's mental health or substance use. ${ }^{241}$ In particular, twenty-eight ask questions about the applicant's current mental health or substance abuse, ${ }^{242}$ with an additional nine asking about the applicant's past as well as current mental health or substance abuse. ${ }^{243}$ Four states ask questions regarding past and current substance use but ask only about current mental health issues. $^{244}$ Two states have questions about current substance abuse but do not have any questions regarding mental health, ${ }^{245}$ and an additional state asks about substance abuse treatment but not about mental health. ${ }^{246}$ Finally, two states ask about past and current instances of mental illness but only current instances of substance abuse. ${ }^{247}$

As one example, the Michigan bar application asks the following questions of its applicants:

Have you ever used, or been addicted to or dependent upon, intoxicating liquor or narcotic or other drug substances . . . [or h] ave you ever had, been treated or counseled for, or refused treatment or counseling for, a mental, emotional, or nervous condition which permanently, presently or chronically impairs or distorts your judgment, behavior, capacity to recognize reality or ability to cope with ordinary demands of life $[; \ldots$ or $]$ which permanently, presently or chronically impairs your ability to exercise such responsibilities as being candid and truthful, handling funds, meeting deadlines, or otherwise representing the interest of others? 248

Given the stigma within the profession, as well as the "unduly intrusive" questions in state bar applications that "likely ... deter" treatment, ${ }^{249}$ it is no surprise that lawyers are reticent to seek treatment. Lawyers with mental health and addiction issues have "pervasive fears surrounding their

241. Arizona, California, Connecticut, Illinois, Massachusetts, New York, Tennessee, Virginia, and Washington.

242. Alabama, Alaska, Colorado, Delaware, District of Columbia, Guam, Idaho, Indiana, Kansas, Kentucky, Louisiana, Maryland, Mississippi, Montana, Nebraska, New Hampshire, New Mexico, North Carolina, North Dakota, Northern Mariana Islands, Oklahoma, Puerto Rico, Rhode Island, South Carolina, South Dakota, Vermont, Virgin Islands, and Wyoming.

243. Florida, Georgia, Maine, Michigan, Minnesota, Missouri, Nevada, Oregon, and Utah.

244. Arkansas, Iowa, New Jersey, and Texas.

245. California, Hawaii, and Pennsylvania.

246. Wisconsin.

247. Ohio and West Virginia.

248. State Bar of Mich., Character \& Fitness Application Preview, https:/ /www.michbar.org/file/professional/pdfs/preview-app.pdf [https://perma.cc/ EBB5-6V8F] (last visited May 7, 2020).

249. Conf. of Chief Justices, Res. 5 (Feb. 13, 2019), https://www.ncsc.org/ __data/assets/pdf_file/0027/23589/07312019-implementation-clear-communications-streamlined-procedures.pdf [https://perma.cc/2TTV-QDGA]. 
reputation" that prevent them from availing themselves of the help that they need. ${ }^{250}$ Accordingly, the two most common barriers for treatment for substance abuse are: (1) "not wanting others to find out they needed help"; and (2) "concerns regarding privacy or confidentiality."251

The statistics demonstrate that these are real barriers to meaningful treatment: only $6.8 \%$ of lawyers surveyed in the Krill study reported seeking treatment for substance use; the two most common barriers-among those who sought and have not sought treatment-are "not wanting others to find out they needed help" and "concerns regarding privacy or confidentiality." 252 The results are even starker for law students. Only $4 \%$ of respondents ever sought help for alcohol or substance use. ${ }^{253}$ And while $42 \%$ of respondents indicated that they thought they needed help for mental health issues, only approximately half have done so. ${ }^{254}$ Further, the greatest reported barriers to seeking treatment include "potential threat to job or academic status," "potential threat to bar admission," and "social stigma." 255

\section{The Business Case for Promoting and Prioritizing LAWyer Well-Being}

As discussed in Part I above, calls have been made to humanize the legal profession for decades. However, throughout most of that time, as The Path to Lawyer Well-Being acknowledged, the profession at large generally has "turned a blind eye" to the pervasiveness of and not done enough to address mental health and addiction issues among its members. ${ }^{256}$ As discussed in Section II.C above, many aspects of the law firm model negatively impact lawyer subjective well-being, which inversely correlates to depression and mental distress. And, as argued in Part III above, law firms and the profession in general have turned such a "blind eye" and ignored the moral case for promoting lawyer well-being because they have not had the financial incentives to change the existing law firm model.

This Part demonstrates how and why it is in law firms' business interest to promote and prioritize their lawyers' well-being. ${ }^{257}$ First, this Sec-

250. Krill et al., supra note 10 , at 51.

251. Id. at 50 .

252. Id.

253. Organ et al., supra note 68 , at 140 . As noted in the text accompanying notes 151-153 above, a significant plurality of law students reported binge drinking, were at risk for alcoholism, or used illicit street drugs or prescription drugs without a prescription.

254. Id.

255. Id. at 141 Help-Seeking tbl.1.

256. See generally The PAth to Lawyer Well-Being, supra note 15, at 11-12 (observing that the profession has "not done enough to help, encourage, or require lawyers to be, get, or stay well").

257. To date, no study has been done to monetize the cost to the legal profession attributable to untreated mental health and addiction disorders, or the corresponding financial gains to the profession by prioritizing lawyer well-being. 
tion argues that law firms incur significant direct and indirect costs related to untreated lawyer mental health and addiction issues. Second, this Section summarizes some of the initial steps taken by firms in recent years to begin to acknowledge and address lawyer well-being issues. Finally, this Section argues that while current efforts are important first steps, the time is ripe for firms to benefit financially from enacting lasting and meaningful change to promote and prioritize lawyer well-being.

\section{A. The Costs of Undermining Lawyer Well-Being}

All professions incur significant costs due to untreated employee mental health and addiction issues. Mental health disorders are by far the most burdensome illnesses to United States employers, costing over \$200 billion each year-well exceeding the cost burden of heart disease, cancer, stroke, and obesity. ${ }^{258}$ Further, the cost of alcohol abuse in the United States is $\$ 249$ billion, with $72 \%$ of that total cost-or over $\$ 179$ billionresulting from losses in workplace productivity. ${ }^{259}$

As recognized by the World Health Organization, the "consequences of mental health problems in the workplace" include, among other things: poor work performance (including "reduction in productivity and output," "increase in error rates," and "poor decision-making") as well as an "increase in disciplinary problems"; absenteeism as well as "loss of motivation and commitment"; "burnout ... . [and] diminishing returns"; and turnover. ${ }^{260}$ That is no different in law firms, where the costs that firms experience due to untreated lawyer mental health and addiction issues include: (1) lawyer disciplinary actions; (2) absenteeism and presenteeism; and (3) costs associated with high attrition. Each is discussed in turn below.

Accordingly, this Section will look to as instructive studies in other and across professions.

258. See Ron Z. Goetzel et al., Mental Health in the Workplace: A Call to Action Proceedings from the Mental Health in the Workplace-Public Health Summit, 60 J. Occupational \& Envtl. Med. 322, 323 (2018) (noting that mental health disorders cost American employers over $\$ 200$ billion a year); $c f$. Matthew Jones, How Mental Health Can Save Businesses \$225 Billion Each Year, INc. (June 16, 2016), http:// www.inc.com/matthew-jones/how-mental-health-can-save-businesses-225-billioneach-year.html [https://perma.cc/S2M9-JYFK]. The World Health Organization estimates that depression and anxiety disorders cost the global economy over $\$ 1$ trillion annually. See Dan Chisholm et al., Scaling-up Treatment of Depression and Anxiety: A Global Return on Investment Analysis, 3 Lancet Psych. 415, 419 (2016).

259. Excessive Drinking Is Draining the U.S. Economy, Ctr. Disease Control \& Prevention, https://www.cdc.gov/features/costsofdrinking/index.html [https:// perma.cc/4B6P-DVYB] (last visited May 7, 2020).

260. Nations for Mental Health, World Health Org., Mental Health ANd Work: Impact, Issues and GoOd Practices 8-9 (2000), https://www.who.int/ mental_health/media/en/712.pdf [https://perma.cc/84WJ-YRQR]. 
Reich: Capitalizing on Healthy Lawyers: The Business Case for Law Firms

\section{Lawyer Discipline: Malpractice and Sanctions}

There can be no question that lawyers who have untreated mental health of addiction disorders can engage in conduct that gives rise to lawyer discipline or malpractice actions. ${ }^{261}$ For instance, according to the ABA, " $40 \%-70 \%$ of disciplinary proceedings and malpractice claims against lawyers involve substance use, depression, or both." ${ }^{262}$ Further, a separate ABA survey covering New York and California found that " 50 to 70 percent of all disciplinary cases involved alcoholism." 263 Reports from other states find similar percentages. ${ }^{264}$

\section{Absenteeism and "Presenteeism"}

In addition to the direct costs of health care and, for lawyers, malpractice and sanctions, firms suffer indirect costs from lawyers struggling with mental health issues. According to one study, businesses suffer over \$102 billion in indirect costs annually due to the absenteeism and "presenteeism" of their depressed employees. ${ }^{265}$ Absenteeism is the amount of work (in hours or days) an employee loses due to illness or otherwise being absent from work. ${ }^{266}$ Presenteeism, as the name suggests, is the amount

261. See, e.g., Badgerow, supra note 51, at 2 (noting that an "alarming number" of complaints against lawyers for ethics violations "involve lawyers' use of and dependence upon drugs and alcohol . . . and descent into depression").

262. The Path to Lawyer Well-Being, supra note 15 , at 8.

263. Carol Langford, Depression, Substance Abuse, and Intellectual Property Lawyers, 53 U. Kan. L. Rev. 875, 902 (2005) (citing Allan, supra note 11, at 268).

264. See, e.g., Attorney Att'y Registration \& Disciplinary Comm'n, Supreme Court of Ill., AnNual Report of 2016, at 35 (2017), https://www.iardc.org/AnnualReport2016.pdf [https://perma.cc/FN2K-XH6V] (indicating that "thirtythree of the 107 lawyers disciplined, or $30.8 \%$, had at least one substance abuse or mental impairment issue"); Lawyers' Fund for the State of N.Y., Annual Report of THE BOARD OF Trustees for CAlendar YeAR 2016, at 14 (2017), http:// www.nylawfund.org/AR2016\%20.pdf [https://perma.cc/8SBC-V95B] (noting that "causes of [lawyer] misconduct are often traced to alcohol, drug abuse, and gam-

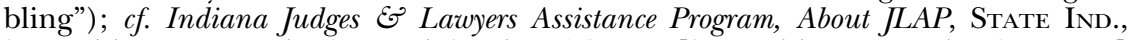
https://www.in.gov/judiciary/ijlap/2361.htm [https://perma.cc/BY5H-NFF9] (last visited May 7,2020 ) (noting that $85 \%$ of calls are about addiction or mental health issues).

265. Paul E. Greenberg et al., The Economic Burden of Adults with Major Depressive Disorder in the United States (2005 and 2010), 76 J. Clinical Psychiatry 155, 159 tbl.2 (2015) (finding that over $\$ 23$ billion of such costs is attributable to absenteeism and nearly $\$ 79$ billion attributable to presenteeism); $c f$. Sameer Kumar et al., Operational Impact of Employee Wellness Programs: A Business Case Study, 58 InT'L J. Productivity \& Performance Mgmt. 581, 583 (2009) (finding that "[d]epressed employees" indirectly cost employers $\$ 52$ billion each year, including $\$ 37$ billion attributable to absenteeism and $\$ 15$ billion attributable to presenteeism. Moreover, active disengagement by employees is estimated to cost businesses more than $\$ 500$ billion annually. See Shawn Achor, Big Potential: How Transforming the Pursuit of Success Raises Our Achievement, Happiness, and Well-Being 102 (2018) [hereinafter, Achor, Big Potential]).

266. See, e.g., Kathryn Rost et al., The Effect of Improving Primary Care Depression Management on Employee Absenteeism and Productivity: A Randomized Trial, 42 MED. CARE 1202, 1204 (2004). 
of work an employee loses while at work because they are unproductive or under-productive. ${ }^{267}$ Mental health and substance abuse issues affect both.

Indeed, studies overwhelmingly demonstrate that "[d]epression substantially reduces an employee's ability to work," as it increases both absenteeism and presenteeism. ${ }^{268}$ According to one study, depression doubles the annual sickness days among employees and results in 2.3 days per month of lost productivity. ${ }^{269}$ Another study found that employees with mental illness reported losing 4.3-5.5 days of productive work in the prior thirty days. ${ }^{270}$ On average, workers with depression have 3.7 times more unproductive time at work per week than those without depression, ${ }^{271}$ and depressed employees generally have "trouble concentrating, greater difficulty in making decisions, and decreased interest in work." 272

In addition to lost workdays and lost productivity, the cost of absenteeism and presenteeism to employers can be monetized. For example, a 2003 study found worker absenteeism and presenteeism due to depression results in costs of $\$ 44$ billion in 2002 dollars to employers. ${ }^{273}$ Additionally, according to another study, $71 \%$ of employer expenditures on employee mental health issues are for lost productivity due to presenteeism. ${ }^{274}$

Moreover, the combination of long hours and all-day availability invariably leads to a lack of sleep. ${ }^{275}$ Not only does fatigue compromise effectiveness, but sustained lack of sleep both leads to cognitive impairment

267. See, e.g., id.

268. Id. at 1202.

269. Philip S. Wang et al., Effects of Major Depression on Moment-in-Time Work Performance, 161 Ам. J. Psychiatry 1885, 1888 (2004).

270. Ronald S. Kessler et al., The Effects of Chronic Medical Conditions on Work Loss and Work Cutback, 43 J. Occupational \& Envtl. Med. 218, 220 tbl.2 (2001); see also Gregory E. Simon et al., Recovery from Depression, Work Productivity, and Health Care Costs Among Primary Care Patients, 22 Gen. Hosp. Psychiatry 153, 153 (2000) (noting that "current depression is associated with an increase of 2 to 4 disability days per month"); see also id. at 154 ("[D] epression is responsible for a tremendous economic burden on employers and insurers.").

271. Walter F. Stewart et al., Cost of Lost Productive Work Time Among US Workers with Depression, 289 JAMA 3135, 3140 (2003).

272. See Kumar et al., supra note 265, at 583; see also Wang et al., supra note 269, at 1887 (finding that major depression "was associated with decrements of approximately 12 points in task focus and approximately 5 points in productivity on their $0-100$ scales ... equivalent to a 0.4 standard deviation increase in task focus and a 0.3 standard deviation decrease in productivity").

273. Stewart et al., supra note 271, at 3141 tbl.4.

274. Ron Z. Goetzel et al., Health, Absence, Disability, and Presenteeism Cost Estimates of Certain Physical and Mental Health Conditions Affecting U.S. Employers, $46 \mathrm{~J}$. Occupational \& Envtl. Med. 398, 408 tbl.4B (2004).

275. Lack of sleep is a natural outgrowth of long hours and total accessibility, and lack of sleep is seen as the cost of exceptional client service. See, e.g., Deborah L. Rhode, Balanced Lives for Lawyers, 70 Fordham L. Rev. 2207, 2211 (2002) ("A common assumption is that client service requires total accessibility."); $c f$. Susan Saab Fortney, The Billable Hours Derby: Empirical Data on the Problems and Pressure Points, 33 Fordham Urb. L.J. 171, 182 (2005) (reporting on survey finding $35.7 \%$ 
Reich: Capitalizing on Healthy Lawyers: The Business Case for Law Firms

and can lead to or exacerbate depression. ${ }^{276}$ With respect to the compromising effectiveness, fatigue "impair[s] judgment and decision making." ${ }^{277}$ For instance, a person who averages four hours of sleep a night for four or five nights will be as cognitively impaired as someone who is legally intoxicated or who has been awake for twenty-four straight hours. ${ }^{278}$ "Within ten days, the level of impairment is the same as . . going forty-eight straight hours without sleep," which significantly "impedes judgment, interferes with problem-solving," and delays reaction times. ${ }^{279}$

As for causing or exacerbating depression, lack of sleep is a "major risk factor in the onset, recurrence, chronicity, and severity" of major depressive episodes. ${ }^{280}$ Accordingly, sleep habits are important and modifiable risk factors to help prevent depression or achieve and maintain depression remission. ${ }^{281}$

Given law firms' reliance on the billable hour as the measure of both lawyer productivity and firm profitability, presenteeism could be seen as a way to maximize profits-after all, a lawyer who can bill more for a task will make more for the firm. However, as discussed below, clients are demanding that firms increase efficiency-both in their services and the methods for which they bill them-thus making presenteeism costly for firms.

of lawyers reported sleeping an average of five-to-six hours per night and $3 \%$ reported sleeping an average of less than five hours per night).

276. Jean M. Twenge, iGen: Why Today's Super-Connected Kids Are Growing up Less Rebellious, More Tolerant, Less Happy-and Completely UnprePared for Adulthood-and What That Means for the Rest of Us 116 (2017) ("Sleep deprivation is linked to myriad issues, including compromised thinking and reasoning, susceptibility to illness, increased weight gain, and high blood pressure. Sleep deprivation also has a significant effect on mood: people who don't sleep enough are prone to depression and anxiety.").

277. Rhode, supra note, at 166; see also Austin, supra note 156, at 837 (arguing that since "sleep deprivation causes loss in cognitive skill-diminished attention, working memory capacity, executive function, quantitative skills, logical reasoning ability, mood, and both fine and gross motor control-law students . . . and lawyers should make adequate regular sleep a priority").

278. Bronwyn Fryer, Sleep Deficit: The Performance Killer, Harv. Bus. Rev. (Oct. 2006), https://hbr.org/2006/10/sleep-deficit-the-performance-killer [https:// perma.cc/TU23-D7NK].

279. $I d$.

280. Jean Twenge et al., Age, Period, and Cohort Trends in Mood Disorder Indicators and Suicide-Related Outcomes in a Nationally Representative Dataset, 2005-2017, 128 J. Abnormal Psychol. 185, 197 (2019); see also Peter L. Franzen \& Daniel J. Buysse, Sleep Disturbances and Depression: Risk Relationships for Subsequent Depression and Therapeutic Implications, 10 Dialogues Clinical Neurosci. 473, 479 (2008); see also Charlotte Fritz et al., Embracing Work Breaks: Recovering from Work Stress, 42 ORG. Dynamics 274, 275 (2013) ("Employees who do not completely recover during the weekend (i.e., they feel that a free weekend is not enough time to recover from the work week) over time are at an increased risk for depressive symptoms, fatigue, energy loss, and cardiovascular disease.").

281. Franzen \& Buysse, supra note 280, at 479. 


\section{Replacement Costs and High Attrition}

Mental health and addiction issues can contribute to lawyer attrition. In general, attrition rates among lawyers are high. In 2016, law firms lost an average of $16 \%$ of associates. ${ }^{282}$ As a general matter, $44 \%$ of associates depart within three years of being hired, and $75 \%$ depart within five years. ${ }^{283}$ Moreover, a 2016 survey found that $40 \%$ of lawyers surveyed were "likely" or "very likely" to be looking for a new job within the next twelve months. ${ }^{284}$ According to one estimate, the cost of replacing a departing associate ranges from $\$ 200,000$ to $\$ 500,000$ - roughly one-and-ahalf to two times the annual salary of that lawyer. ${ }^{285}$ This cost-which could include advertising, recruiters' time and salary, interviewing expenses, and training-does not account for implicit costs. Such costs, including lost productivity time, covering the work of the departing lawyer, and disrupted intrafirm and client relationships, "can dwarf the explicit expenses." 286 Thus, taking the midpoint and ignoring the implicit cost of attrition, associate attrition costs a firm with 100 associates $\$ 5.6$ million and a firm with $500 \$ 28$ million annually. ${ }^{287}$

\section{B. Incremental Efforts to Address Lawyer Well-Being}

In the wake of the Task Force's 2017 call to action in its The Path to Lawyer Well-Being report, some law firms and other legal employers have

282. NALP Found., Update on Associate Attrition 12 tbl.6 (2017).

283. Id. at 11 tbl.5.

284. 2016 Lawyer Satisfaction Survey: By the Numbers, Law360 (Sept. 2, 2016), https:/ / www.law360.com/articles/833246/law360-s-2016-lawyer-satisfaction-surveyby-the-numbers [https://perma.cc/X35K-52N8].

285. Levit \& Linder, supra note 13, at 162 (citation omitted); see also Leslie Larkin Cooney, Walking the Legal Tightrope: Solutions for Achieving a Balanced Life in Law, 478 S.D. L. Rev. 421, 427 (2010) ("The average cost to a law firm when an associate leaves has been documented at $\$ 315,000$; while others estimate that it costs a firm $150 \%$ of a person's annual salary when she quits.”).

286. Levit \& Linder, supra note 13, at 162 (citation omitted); see also RHODE, supra note 166, at 15; Peter H. Huang \& Rick Swedloff, Authentic Happiness $\mathcal{E}$ Meaning at Law Firms, 58 Syr. L. REv. 335, 336 (2008) ("Attrition of associates is costly to law firms, in terms of money, morale, reputation, and time."); Seligman et al., supra note 13, at 33 ("Unhappy associates fail to achieve their full potential at a cost to them, their firms, their clients, and even their families.").

287. 100 lawyers $\times 16 \%=16 ; 16 \times \$ 350,000=\$ 5,600,000.500$ lawyers $\times 16 \%=$ $80 ; 80 \times \$ 350,000=\$ 28,000,000$.

Further, firms that fail to adequately promote the well-being of their lawyers may face the cost of attrition when that failure is seemingly most acute. For example, after Gabe McConaill's death (see supra notes 1-4 and accompanying text), "a number of employees" reportedly left his firm's Los Angeles office, purportedly because "they thought that the firm's leadership did not respond sufficiently in the wake of [his] death," and that "there was no clear commitment to support employees who ... found [the firm's] demanding corporate culture an unwelcome environment in which to raise a hand" to seek help. Lilah Raptopoulos \& James Fontanella Khan, The Trillion-Dollar Taboo: Why It's Time to Stop Ignoring Mental Health at Work, Fin. Times (July 10, 2019), https://www.ft.com/content/1e8293f4a1db-11e9-974c-ad1c6ab5efd1 [https://perma.cc/P3PL-MHN7]. 
Reich: Capitalizing on Healthy Lawyers: The Business Case for Law Firms

begun to, at least, recognize the mental health and addiction issues in the profession, and some have taken incremental steps to promote the wellbeing of their lawyers. While first steps are helpful toward addressing the crisis, there is still a long way for the profession to go to enact meaningful and lasting change. ${ }^{288}$

As an initial step, some firms have at least begun to acknowledge that mental health and addiction problems exist in the profession. For instance, in a Summer 2018 survey of managing partners and human resources officials at Am Law 200 law firms on mental health and substance abuse, $86 \%$ of those surveyed either agreed or strongly agreed that depression occurs at their firm, and $93 \%$ agreed or strongly agreed that anxiety occurs at the firm. ${ }^{289}$ Further, $90 \%$ agreed or strongly agreed that alcohol abuse occurs at the firm, and $48 \%$ agreed or strongly agreed that drug abuse occurs at the firm. ${ }^{290}$ And these firms recognize that their cultures contribute to these problems: when asked to rank the "causes of substance abuse and mental health problems in the law firm environment," $79 \%$ of respondents listed "stress and workload" as the principle cause. ${ }^{291}$

As an additional step, in September 2018 the ABA launched a campaign seeking to "raise awareness, facilitate a reduction in the incidence of problematic substance use and mental health distress and improve lawyer well-being." 292 To that end, the ABA developed a "seven-point framework for building a better future" for lawyer well-being ${ }^{293}$ and requested firms

288. Patrick Krill, Progress, Not Perfection, Is Key to Law Firms'Mental Health Programs, LAw.COM (June 12, 2019), https:/ /www.law.com/2019/06/12/progress-notperfection-is-key-to-law-firms-mental-health-programs/ [https://perma.cc/GH6AWR23] [hereinafter Krill, Progress, Not Perfection] (noting the "huge canyon between where the profession is now and where we might otherwise want it to be").

289. ALM INTELLIGENCE, supra note 235.

290. Id.

291. Id. In conducting the survey, the surveyors "noted that "discussing substance abuse and mental health issues has often been considered taboo in the legal industry.'" Patrick Krill, ALM Survey on Mental Health and Substance Abuse: Big Law's Pervasive Problem, Law.com (Sept. 14, 2018), https://www.law.com/2018/09/14/ alm-survey-on-mental-health-and-substance-abuse-big-laws-pervasive-problem/ [https://perma.cc/CRX4-RBZY]. The survey yielded a response rate of only $15 \%$, which "would seem to suggest that the taboo is alive and well." Id.; see also supra notes 235-237 and accompanying text.

292. See ABA Launches Pledge Campaign to Improve Mental Health and Well-Being of Lawyers, Aм. B. Ass'N (Sept. 10, 2018), https://www.americanbar.org/news/aba news/aba-news-archives/2018/09/aba-launches-pledge-campaign-to-improvemental-health-and-well-b/ [https://perma.cc/SL3P-QERD] [hereinafter $A B A$ Launches Pledge Campaign].

293. These seven points are: (1) "Provide enhanced and robust education to lawyers and staff on topics related to well-being, mental health, and substance use disorders"; (2) Disrupt the status quo of drinking-based events"; (3) "Develop visible partnerships with outside resources committed to reducing substance use disorders and mental health distress in the profession ..."; (4) "Provide confidential access to addiction and mental health experts and resources, including free, inhouse, self-assessment tools"; (5) "Develop proactive policies and protocols to support assessment and treatment of substance use and mental health problems, in- 
sign a pledge of support for the ABA's campaign. The pledge provides as follows:

Recognizing that substance use and mental health problems represent a significant challenge for the legal profession, and acknowledging that more can and should be done to improve the health and well-being of lawyers, we the attorneys of [FIRM] hereby pledge our support for this innovative campaign and will work to adopt and prioritize its seven-point framework for building a better future. ${ }^{294}$

Thirteen law firms initially signed the pledge upon its September 2018 issuance. ${ }^{295}$ The ABA called upon "all legal employers" to take the pledge by January, 1, 2019;296 through May 2020, only 133 law firms (and fifty other organizations) had done so. ${ }^{297}$

In addition to acknowledging mental health and addiction issues and pledging to take theoretical steps to improve lawyer well-being, firms have

cluding a defined back-to-work policy following treatment"; (6) "Actively and consistently demonstrate that help-seeking and self-care are core cultural values, by regularly supporting programs to improve physical, mental[,] and emotional wellbeing"; and (7) "Highlight the adoption of this well-being framework to attract and retain the best lawyers and staff." See Presentation, Challenging the Status Quo: A Campaign of Innovation to Improve the Substance Use and Mental Health Landscape of the Legal Profession, Ам. B. Ass'N, https://www.americanbar.org/content/dam/aba/ad ministrative/lawyer_assistance/ls_colap_working_group_pledge_and_campaign. authcheckdam.PDF [https://perma.cc/WF7X-P7FT] (last visited May 7, 2020).

294. Am. Bar Ass'n, Pledge Commitment Form 1, https://www.american bar.org/content/dam/aba/administrative/lawyer_assistance/ls_colap_working group_pledge_commitment_form.authcheckdam.pdf [https://perma.cc/M67SVJ6S] (last visited May 7, 2020).

295. The law firms are:

Akin Gump Strauss Hauer \& Feld LLP; Corette Black Carlson \& Mickelson P.C.; Duane Morris LLP; Honigman Miller Schwartz \& Cohn LLP; Latham \& Watkins LLP; Morgan, Lewis \& Bockius LLP; Nixon Peabody LLP; Perkins Coie LLP; Reed Smith LLP; Schiff Hardin LLP; Seyfarth Shaw LLP; Snell \& Wilmer LLP; and Wiley Rein LLP.

ABA Launches Pledge Campaign, supra note 292.

296. Id.

297. Working Group to Advance Well-Being in the Legal Profession, Aм. B. Ass'N, https://www.americanbar.org/groups/lawyer_assistance/working-group_to_ad vance_well-being_in_legal_profession/ [https://perma.cc/Y4ST-4G6Q] (last visited June 1, 2020). Interestingly, perhaps in a sign of a change of the times, the firm whose chairman warned of client perception of employing "crazy lawyers" is one of the signatories to the ABA's pledge. Id.; cf. OnAir with Akin Gump: Mental Health $\mathcal{E}^{\circ}$ Well-Being in the Legal Industry with Kim Koopersmith, Patrick Krill, AKIN GuMP (June 18, 2019), https://www.akingump.com/en/news-insights/mentalhealth-well-being-in-the-legal-industry-with-kim.html [https://perma.cc/6GQWZKAJ] (in an interview with the chairman of an Am Law 100 firm, the creator of the well-being pledge describes how he "was essentially laughed off the stage as being a well-intentioned idiot" when he first proposed it to a group of lawyers a few years prior to its launch). 
been beginning to take concrete steps to address them, ${ }^{298}$ with some efforts even predating the formal call to action in The Path to Lawyer WellBeing. These programs include continuing education courses, visiting speakers, online resources, and social opportunities promoting healthy lifestyles, as well as employee assistance programs and direct access to professional services. ${ }^{299}$ For instance, since 2016, Kirkland \& Ellis has offered yoga, meditation, and wellness training to its lawyers. ${ }^{300}$ In 2017, the New York and Washington, D.C. offices of Hogan Lovells started offering onsite psychologists to their employees; ${ }^{301}$ also in 2017, Akin Gump Strauss Hauer \& Feld began offering its lawyers the services of on-site behavioral assistance counselors as part of its overall "Be Well" program, which it started the year before. ${ }^{302}$ Further, in 2019, Morgan Lewis launched an employee well-being program entitled "ML Well," and created a "Director of Employee Well-Being" position. ${ }^{303}$

Moreover, beyond firms themselves, some state bars have taken action to eliminate questions on bar applications relating to an applicant's mental health history. In February 2019, the Conference of Chief Justices, in recognition that questions about mental health history, diagnoses, or treatment are "unduly intrusive" and "likely to deter individuals from seeking mental health counseling and treatment," passed a resolution urging state and territorial bar authorities to eliminate such questions from bar applications. ${ }^{304}$ The conference resolved that it is reasonable to ask about an applicant's mental health history "only ... if the applicant has engaged in conduct or behavior and a mental health condition has been offered or shown to be an explanation for such conduct or behavior." 305 Consistent

298. See generally Dan Packel, Law Firms Tackle Mental Health, One Initiative at a Time, Am. LAw. (June 17, 2019), https://www.law.com/americanlawyer/2019/06/ 17/law-firms-tackle-mental-health-one-initiative-at-a-time/ [https://perma.cc/ ZEG6-VZC6] (summarizing law firms' programs and other steps to improve lawyer and staff mental health and wellness).

299. See id.

300. Claire Bushey, Kirkland E Ellis to Offer Wellness Training to All U.S. Lawyers, Crain's Chi. Bus. (May 2, 2016), https://www.chicagobusiness.com/article/ 20160502/NEWS04/160509972/kirkland-ellis-to-offer-wellness-training-to-all-u-slawyers [https://perma.cc/TB8X-SQAM].

301. Randazzo, supra note 22.

302. Ryan Lovelace, Akin Gump Adds On-Site Counseling as Firms Fret over Mental Health, NAT'L L.J. (May 15, 2017), http://www.law.com/nationalawjournal/2018/ 05/15/akin-gump-adds-on-site-counseling-as-firms-fret-over-mental-health/ [https://perma.cc/7AY8-5YMX].

303. Morgan Lewis Launches ML Well Program, Morgan Lewis (Mar. 18, 2019), https://www.morganlewis.com/news/morgan-lewis-launches-ml-well-program [https://perma.cc/V48C-SE5T].

304. Conf. of Chief Justices, Res. 5, supra note 249.

305. Id. In August 2015, the ABA adopted a similar resolution, which called upon state bars to "eliminate any questions that ask about mental health history, diagnoses, or treatment and instead focus questions on conduct or behavior that impairs an applicant's ability to practice law in a competent, ethical, and professional manner.” Am. B. Ass'n Res. 102 (Aug. 3, 2015). 
with the conference's resolution, in 2019 three states-Connecticut, ${ }^{306}$ Virginia, ${ }^{307}$ and Wisconsin ${ }^{308}$-removed questions relating to applicants' mental health history (except when offered as a defense to conduct). Further, California and New York began examining whether they should remove such questions from their respective bar applications. ${ }^{309}$ As a consequence of these examinations, in July 2019 California enacted legislation prohibiting its state bar from seeking applicants' mental health records beginning on January 1, 2020,310 and on March 1, 2020, New York Court of Appeals Chief Justice Janet DiFiore announced that mental health-related questions would be removed from bar applications effective immediately. ${ }^{311}$

These pioneering steps are a helpful-and much needed-start to addressing lawyer mental health and addiction issues and well-being issues more generally. ${ }^{312}$ However, more firms and legal employers need to take

306. See Connecticut Bar Examining Committee, Conn. Jud. Branch, https:/ /www.jud.ct.gov/cbec/instadmisap.htm\#Forms [https://perma.cc/EKF5-4QKQ] (last visited May 7, 2020). See generally Editorial, Long Overdue Step Taken to Remove Mental Health Stigma in Law, Conn. L. TRIB. (Apr. 12, 2019), https://www.law.com/ ctlawtribune/2019/04/12/long-overdue-step-taken-to-remove-mental-healthstigma-in-law/ [https://perma.cc/9FXM-WDZT].

307. Sample Forms, VA. BD. B. Examiners, http://barexam.virginia.gov/misc/ resources/samples.html [https://perma.cc/49YH-AGEY] (last visited May 7, 2020). The Virginia State Bar removed questions relating to mental health history and treatment in response to organized law student effort for it to do so. Justin Mattingly, Virginia Panel Scraps Mental Health Question After Law School Student Push, Richmond Times-Dispatch (Feb. 8, 2019), https://www.richmond.com/news/lo$\mathrm{cal} /$ education/virginia-panel-scraps-mental-health-question-after-law-school-stu dent/article_36ece9b3-078c-5e12-b748-762555b8f081.html [https://perma.cc/ T8H7-WA3N].

308. See generally For Attorneys: Admission to the Practice of Law in Wisconsin, Wis. CT. Sys., https://www.wicourts.gov/services/attorney/bar.htm [https://perma.cc/ Q9S4-5BQE] (last visited May 7, 2020).

309. Susan DeSantis, Momentum Builds for Allowing NY Bar Applicants to Keep Mental Health History Secret, N.Y.L.J. (June 10, 2019), https://www.law.com/new yorklawjournal/2019/06/10/momentum-builds-for-allowing-ny-bar-applicants-tokeep-mental-health-history-secret/ [https://perma.cc/AY3F-3CLH].

310. See Cal. Bus. \& Prof. Code $\S 6060$ (b) (2) (2020).

311. Christian Nolan, Law School Grads in NY Won't Face Mental Health Inquiry, N.Y.S. BAR Ass'N (Mar. 1, 2020), https://nysba.org/mentalhealthinquiry/ \#: :text=in\%20a\%20major\%20victory\%20for,state\%20bar\% 20application\%20ef

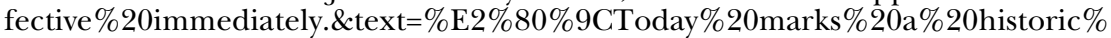
20step,said\% 20NYSBA\%20President\%20Hank\%20Greenberg. [https:// perma.cc/3UDS-NLCX].

312. Additionally, legal trade publications are speaking more to mental health and addiction issues in the profession. For instance, in May 2019, the website Law.com and its affiliate websites launched "Minds over Matters," a year-long "examination into mental health, stress, addiction, and overall well-being in the profession," which includes "articles, analysis, data, expert advice, personal stories of triumph, a resource center . . . and much more." Gina Passarella Cipriani \& Leigh Jones, Introducing Minds over Matters: A Yearlong Examination of Mental Health in the Legal Profession, LAw.com (May 12, 2019), https://www.law.com/2019/05/ 12/introducing-minds-over-matters-a-yearlong-examination-of-mental-health-inthe-profession/ [https://perma.cc/6R4X-KWP9]. See generally Mind Over MAT- 
action to enable meaningful, profession-wide change. And, of the efforts currently being made by firms, there is some concern that, however wellmeaning, they "lack the teeth to address the toughest of the issues," 313 or are "little more than window dressing-a way for firms to check a box and show they are making a difference while avoiding the more complex process of a true reckoning." 314 As one associate put it, "the fixes being offered [by firms] are 'like a band-aid over a bullet wound." "315

Indeed, a 2020 study by ALM, which is based on the results of a survey of nearly 4,000 lawyers, demonstrates that more work needs to be done. ${ }^{316}$ The study found that $41.2 \%$ of respondents feel that mental health and addiction problems in the legal profession have reached a "crisis level." 317 In particular, that study reported that:

- $31.2 \%$ of respondents reported feeling depressed;

- $64 \%$ reported feeling anxiety;

- $32.7 \%$ reported increasing their drug or alcohol use as a result of work;

- $17.9 \%$ reported that they have contemplated suicide over the course of their legal career;

- $67 \%$ reported that their personal relationships have suffered as a result of their being in the legal profession; and

- $74.1 \%$ reported feeling that the legal profession has had a negative effect on their mental health. ${ }^{318}$

Although not scientifically validated, this study's findings suggest the prevalence of mental distress and addiction issues at the same or greater levels than those reported in the Krill Study. ${ }^{319}$

Nevertheless, it would be counterproductive to reject this progress as less than the complete culture change or paradigm shift needed to ad-

ters: An Examination of Mental Health in the Legal Profession, Law.com, https://www.law.com/special-reports/minds-over-matters-an-examination-of-men tal-health-in-the-legal-profession/ [https://perma.cc/manage/create?folder=839384673] (last visited May 7, 2020).

313. Gina Passarella Cipriani, 'Like a Band-Aid over a Bullet Wound': The Disconnect Between Firms and Lawyers on Wellbeing Efforts, LAw.com INT'L (June 30, 2019, 7:00 PM), https://www.law.com/international-edition/2019/06/30/like-a-bandaid-over-a-bullet-wound-the-disconnect-between-firms-and-lawyers-on-well-being-efforts-378-112902/ [https://perma.cc/GVA2-XPTF].

314. Packel, supra note 298.

315. Passarella Cipriani, supra note 313.

316. See Lizzy McLellan, Lawyers Reveal True Depth of Mental Health Struggles, LAw.cOM (Feb. 19, 2020, 11:00 AM), https://www.law.com/2020/02/19/lawyersreveal-true-depth-of-the-mental-health-struggles/ [https://perma.cc/933E-72UD].

317. Id.

318. Id.; see also By the Numbers: The State of Mental Health in the Legal Industry, LAw.COM (Feb. 19, 2020), https://www.law.com/2020/02/19/by-the-numbers-thestate-of-mental-health-in-the-legal-industry/ [https://perma.cc/XRN5-5LAH] (featuring key data points from survey).

319. Krill et al., supra note 10; see also supra notes 58-66 and accompanying text. 
dress lawyer mental health and addiction issues in meaningful ways. ${ }^{320}$ Incremental progress could allow the profession to build the bridge toward the systemic changes the profession needs. ${ }^{321}$ However, the systemic changes needed may come about more quickly if firms recognize not just the social good in prioritizing their lawyers' well-being (which has long been one of the principal justifications in calls for systemic change), but the benefits that will inure to firms' bottom lines and profit margins. The next section explains why the time is right for these systemic changes, and why it is in firms' financial interests to make them.

\section{The Financial Benefits of Lasting and Meaningful Change}

The time is right for firms to prioritize lawyer well-being in part because we are at a tipping point in mental health awareness. While stigma about mental health certainly still exists-particularly in law firms ${ }^{322}$ people involved in entertainment, ${ }^{323}$ sports, ${ }^{324}$ and politics ${ }^{325}$ have all

320. Krill, Progress, Not Perfection, supra note 288 ("Standing on the edge [of the canyon] while complaining about the width of the chasm won't do anything to narrow its yawn.").

321. Id.

322. See supra notes 235-237 and accompanying text.

323. See, e.g., Sandra Gonzalez, Emma Stone Opens up About Ongoing Battle with Anxiety, CNN (Oct. 2, 2018, 3:00 PM), https://www.cnn.com/2018/10/02/entertainment/emma-stone-anxiety/index.html [https://perma.cc/ZGQ6-PEWB]; Cydney Henderson, Chris Evans Reveals He Almost Turned Down "Captain America" over Anxiety, USA TODAY (May 26, 2020, 11:44 PM), https://www.usatoday.com/ story/entertainment/celebrities/2020/05/26/chris-evans-almost-turned-downcaptain-america-over-anxiety/5264260002/ [https://perma.cc/9CPT-ALSD?type= image]; see also Wale Says Record Deals Should Include Mental Health Assistance, VIBE (Oct. 11, 2019, 10:07 PM), https:/ /www.vibe.com/2019/10/wale-says-record-dealsinclude-mental-health-assistance [https://perma.cc/LPU6-J7KF].

324. See, e.g., Kevin Love, Everyone Is Going Through Something, Players' Trib. (Mar. 6, 2018), https://www.theplayerstribune.com/en-us/articles/kevin-love-everyone-is-going-through-something [https://perma.cc/99M3-B3ZB]; see also, e.g., Jackie MacMullan, The Courageous Fight to Fix the NBA's Mental Health Problem, ESPN (Aug. 20, 2018), http://www.espn.com/nba/story/_/id/24382693/jackie-macmullan-kevin-love-paul-pierce-state-mental-health-nba [https://perma.cc/NCH9BZDK]. Professional hockey player Robin Lehner won the National Hockey League's Masterton Trophy as the "player who best exemplifies the qualities of perseverance, sportsmanship, and dedication to ice hockey" for the 2018-2019 season after going public with his battle with addiction and mental illness. Dan Rosen, Lehner Uses Masterton Trophy to Continue Mental-Health Message, NHL (June 20, 2019), https://www.nhl.com/news/lehner-uses-masterton-to-continue-message/c307928992?tid=280503612 [https://perma.cc/C2GM-REEZ]. In his speech accepting the award, he proclaimed: "I'm not ashamed to say I'm mentally ill, but that doesn't mean [I'm] mentally weak." Id. (internal quotation marks omitted).

325. See, e.g., Jason Kander, I Suffer from Depression and Have PTSD Symptoms, Medium (Oct. 2, 2018), https://medium.com/@JasonKander/about-four-monthsago-i-contacted-the-va-to-get-help-2dc6006804c1 [https://perma.cc/L7FA-9F6D]; Tina Smith, U.S. Senator Tina Smith in Senate Speech: "Why I'm Sharing My Experience with Depression," Senator Tina Smith (May 15, 2019), https://smith.senate.gov/ussenator-tina-smith-senate-speech-why-im-sharing-my-experience-depression [https://perma.cc/VH3B-UT74]. 
raised awareness of mental health and addiction issues by coming forward to share stories of their personal struggles. Further, many other industries have taken steps to prioritize mental health. ${ }^{326}$ And, while "law firms remain 20 years behind corporate America when it comes to taking measures to improve mental health," 327 it is in firms' interest to catch up to other professions and industries as prioritizing lawyer well-being will help firms recruit and retain the best talent.

As noted above, the profession has made progress and both recognizing the problems and taking incremental steps to address them are positive steps. This should be acknowledged and applauded. But making lasting, meaningful change in the profession requires a shift in the paradigm within which firms operate at both the organizational and profession-wide levels. After all, as one law firm consultant observed, "the mixed messages sent when a firm says 'go use our meditation room but make sure you bill 2,000 hours or you won't get your bonus' need a broader fix that may require more people in the room than those focused purely on mental health." 328 As the ABA recognized in The Path the Lawyer Well-Being, "[b]road-scale change requires buy-in and role modeling from top leadership."329

That buy-in from firm leadership-i.e., those that have helped create and perpetuate the commodification of the legal profession as well as the stigma attached to lawyers with mental health and addiction issues-will not come unless and until that leadership sees a potential return on such an investment.

As explained in Section IV.A above, law firms and legal employers experience costs when lawyer mental health and addiction issues are unaddressed. A number of interventions can significantly lessen the burden of depression or anxiety in the workplace, and specifically work-related interventions can have a positive role in maintaining mental health and facilitating recovery from depression or anxiety. ${ }^{330}$ Primary and secondary prevention approaches demonstrate "either moderate or strong efficacy in terms of reducing symptom severity." ${ }^{331}$ Thus, workplace interventions

326. See generally infra notes 340-345 and accompanying text.

327. Packel, supra note 298.

328. Id.

329. The Path to Lawyer Well-Being, supra note 15, at 11-12. At least one senior partner at an international law firm has publicly advocated for such broadscale change, penning an open letter calling for firms to rethink billing and compensation practices-specifically "de-emphasiz[ing] the billable hour or [doing] away with it completely" - in response to the profession's "mental health crisis." Jane Cohen Barbe, Open Letter from Dentons Partner: Mental Health Crisis Requires Rethinking Firm Business Models, Law.COM (July 31, 2019), https://www.law.com/ 2019/07/31/open-letter-from-dentons-partner-the-mental-health-crisis-requires-re thinking-firm-business-models/ [https://perma.cc/C3QM-Y6GD].

330. S. Joyce et al., Workplace Interventions for Common Mental Disorders: A Systemic Meta-Review, 46 Psychol. Med. 683, 692 (2016).

331. Id. 
and treatment initiatives can help obviate the costs discussed above. Moreover, these interventions lead to reductions in health care costs (and therefore insurance premiums). The costs associated with promoting wellness are significantly outweighed by the financial benefits. According to one study, for every dollar a company spends on employee wellness programs, medical costs fall by $\$ 3.27$ and increased costs attributed to employee absenteeism fall by $\$ 2.73 .{ }^{332}$ Further, more generally, a 2016 study estimated that every dollar spent to "scale up" treatment for mental illness between 2016 and 2030 within the thirty-six largest nations will yield $\$ 4.00$ in increased productivity and the ability to work. ${ }^{333}$

In addition to these financial savings, healthier workers are more productive, and prioritizing lawyer well-being will likely help with lawyer retention and recruitment. ${ }^{334}$ This is especially true now, with the growth of alternative fee arrangements as opposed to traditional hourly fee structures and the increasing importance millennial and now Generation $\mathrm{Z}$ lawyers and law students place on mental health and work-life balance.

As set forth below, firms that prioritize lawyer health and well-being similarly will see the indirect benefits of: (1) better performance from their lawyers and staff; (2) better retention; and (3) better yield of incoming lawyers through recruitment.

\section{Performance: Client Demands for Efficiency}

As discussed in Section IV.A.2 above, mental health and addiction disorders result in increased absenteeism and presenteeism. Indeed, the stress faced by lawyers results not only in a decline in their well-being and rise in anxiety, panic attacks, depression, substance abuse, and suicide, but

332. Katherine Baicker et al., Workplace Wellness Programs Can Generate Savings, 29 Health Aff. 304, 308 (2010); see also Rhode, supra note 166, at 23 ("Some estimates suggest that every dollar invested in policies concerning quality of life results in two dollars saved in other costs."). As one example, Coors Brewing Company reported a $\$ 6.15$ return in profitability for every dollar spent on its corporate fitness program. Achor, Happiness Advantage, supra note 101, at 57-58 (citing Jim Loehr \& Tony Schwartz, The Power of Full Engagement: Energy, Not Time, Is the Key to High Performance and Personal Renewal 65 (2003)).

333. Chisholm et al., supra note 258, at 415, 420-21. Specifically, the study estimated that while net present value (NPV) of this "scale-up" cost is $\$ 147$ billion, the NPV of the resulting increased productivity in the workforce is \$399 billion, with an additional $\$ 310$ billion in additional "healthy life-years." Id.

334. See Baicker et al., supra note 332, at 304; see also id. at 310 ("Although these benefits surely accrue in part to the employee, it is also likely that they accrue in part to the employer-in the form of either lower replacement costs for absent workers or an advantage in attracting workers to the firm."). Data from a survey published in March 2018 of nearly 65,000 federal government employees provided "strong evidence of the positive association between employee use of work-life programs and high organizational performance, retention, and job satisfaction." U.S. Off. of Pers. Mgmt., Federal Work-Life Survey Governmentwide Report 5 (2018), https://www.opm.gov/policy-data-oversight/worklife/federal-work-life-survey/2018-federal-work-life-survey-report.pdf [https://perma.cc/4CX7-DBTR]. 
Reich: Capitalizing on Healthy Lawyers: The Business Case for Law Firms

also in diminished cognitive capacity. ${ }^{335}$ It is no surprise, then, that treatment for depression "significantly improve[s] productivity" and improves absenteeism, ${ }^{336}$ and substance abuse treatment similarly greatly reduces both presenteeism and absenteeism. ${ }^{337}$ Consequently, as a practical matter, more engaged employees generate higher business incomes. ${ }^{338}$ And, as recognized by a study of federal employees, employees are "significantly more likely" to receive high performance ratings if they participate in wellness programs, employee assistance programs, or similar wellness-based policies. ${ }^{339}$

Recognizing this, several companies outside the legal profession have engaged in what Whole Foods founder John Mackey and economist Raj Sisodia have termed "conscious capitalism" - a system whereby businesses "simultaneously create[] multiple kinds of value and well-being for all stakeholders: financial, intellectual, physical, ecological, social, cultural, emotional, ethical, and even spiritual."340 As they explain, conscious businesses "place a huge emphasis on improving the health and well-being of [their] team members," under the belief that when employees are healthy, the company not only generates higher revenue (because the employees do better work and provide better services to customers) but it also spends less money on health care. ${ }^{341}$ As a consequence, such businesses "enhance the[ir] bottom line" through programs that promote employee health and well-being, including onsite gyms, nutrition programs, worklife balance programs, mindfulness training, and stress management classes. ${ }^{342}$ These businesses take their employees' physical and mental health

335. Austin, supra note 156 , at 796-97.

336. Rost et al., supra note 266, at 1206; see also id. at 1208 ("The improvements in absenteeism and productivity we observed in the total cohort were largely due to the improvements consistently employed workers realized from intervention.").

337. Eli Jordan et al., Economic Benefit of Chemical Dependency Treatment to Employers, 34 J. Substance Abuse Treatment 311, 315-17 (2008).

338. James K. Harter et al., Business-Unit-Level Relationship Between Employee Satisfaction, Employee Engagement, and Business Outcomes: A Meta-Analysis, 87 J. ApPLIED PsychOL. 268, 275 (2002) (noting "the correlation between employee engagement and business outcomes, even conservatively expressed, is meaningful from a practical perspective"); see also id. ("On average, business units in the top quartile on the employee engagement measure produced 1 to 4 percentage points higher profitability."); Sonja Lyubomirsky et al., The Benefits of Frequent Positive Affect: Does Happiness Lead to Success?, 131 Psychol. Bull. 803, 803, 840 (2005) (noting the correlation between happiness among employees and business success because "positive affect engenders success," and it also "affect[s] . . . the following resources, skills, and behaviors: sociability and activity . . , altruism . . , liking of self and others . . . , strong bodies and immune systems . . ., and effective conflict resolution skills").

339. Federal Work-Life Survey Governmentwide Report, supra note 334, at 9. See generally id. at $36-41$.

340. John Mackey \& Raj Sisodia, Conscious Capitalism 32 (2013).

341. Id. at 96 .

342. Austin, supra note 156, at 798. 
seriously, and they "encourage positive emotional energy in the workplace to promote intellectual vigor and enhance productivity." 343

Unsurprisingly, conscious businesses perform exceptionally well financially. For instance, a sample of conscious businesses outperformed the overall stock market by a ratio of 10.5:1 over a fifteen-year period from 1996-2011. ${ }^{344}$ These businesses delivered more than 1,646\% returns when the market was up only $157 \%$ over that period. ${ }^{345}$

Moreover, research on mindfulness and happiness generally is instructive on the benefits of well-being to employee performance. First, beyond formal wellness programs, firms that promote mindfulness can help to manage and reduce lawyer distress and also enable their lawyers to provide exceptional client service. ${ }^{346}$ Practicing mindfulness can help lawyers feel and perform better, ${ }^{347}$ improve lawyer decision-making, ${ }^{348}$ ethics, ${ }^{349}$ and even active listening and negotiation skills. ${ }^{350}$ In fact, lawyers at an international law firm reported a $45 \%$ increase in focus, a $35 \%$ decrease in stress, and a $35 \%$ increase in effectiveness after completing a firm-sponsored mindfulness program..$^{351}$

Second, happiness research has demonstrated that happiness correlates to successful outcomes because "positive affect engenders success." 352 Happiness is inextricably linked to work satisfaction, as " $[\mathrm{t}]$ he number one determinant of happiness is 'a good job': work that is meaningful and

343. Edward M. Hallowell, Shine: Using Brain Science to Get the Best From Your People 31 (2011). Moreover, corporations have increasingly recognized their commitment to all stakeholders beyond shareholders. For instance, in August 2019, the Business Roundtable-an association of CEOs of America's leading companies-issued a "Statement on the Purpose of a Corporation," in which it announced their respective corporations are committed to, among other things, "[i]nvesting in our employees." Bus. Roundtable, Statement on the Purpose of A Corporation (2019), https://opportunity.businessroundtable.org/ourcommitment/ [https://perma.cc/4SPY-JVUR].

344. MACKEY \& Sisodia, supra note 340, at 278 .

345. See id. at 278 tbl.A-1; id. at 35-36.

346. Leonard L. Riskin, The Contemplative Lawyer: On the Potential Contributions of Mindfulness Meditation to Law Students, Lawyers, and Their Clients, 7 Harv. Negot. L. Rev. 1, 8 (2002).

347. Id. at $46-48$.

348. Peter H. Huang, Can Practicing Mindfulness Improve Lawyer Decision-Making, Ethics, and Leadership?, 55 Hous. L. Rev. 63, 79-80 (2017).

349. Id. at 101.

350. Riskin, supra note 346, at 48-60.

351. Felicity Nelson, Mindfulness Training an Antidote to Lawyers' Toxic Lives, LAw. WKLY. (Dec. 18, 2015), https://www.lawyersweekly.com.au/news/17721-mind fulness-training-an-antidote-in-lawyers-toxic-lives [https://perma.cc/FT9N-GY4E]. As an additional example, insurance company Aetna found that its fifteen-thousand employees that took part in a training program designed to teach them meditation and yoga found an average gain of "62 minutes of productivity [per] week." Shawn Achor \& Michelle Gielan, The Busier You Are, the More You Need Mindfulness, Harv. Bus. Rev. (Dec. 18, 2015), https://hbr.org/2015/12/the-busier-you-are-themore-you-need-mindfulness [https://perma.cc/GMH9-TSKN].

352. Lyubomirsky et al., supra note 338 , at 803. 
done in the company of people we care about."353 In a word, happiness is actually the cause of success, not merely the result. ${ }^{354}$

In fact, studies have found a strong correlation between happy employees and objective and subjective measures of productivity, ${ }^{355}$ and as a general matter positive affect can improve not only skills important for effective lawyering (such as sociability, altruism, and conflict resolution), but physical health as well. ${ }^{356}$ Engaged workers perform better because they often "experience positive emotions, including happiness, joy, and enthusiasm; experience better health; create their own job and personal resources; and transfer their engagement to others." 357

Just as a negative environment can impact employees negatively, a positive environment can impact them positively. Research demonstrates that we can "pick up negativity, stress, and apathy" from others; simply observing a co-worker's stress "can have an immediate effect upon our own nervous systems, raising our levels of the stress hormone cortisol by as much as 26 percent." 358 By contrast, "the presence of even one positive person in a community can actually 'infect' everyone in it with positivity."359 Put differently, working with positive, engaged, motivated people enhances our own positivity, engagement, motivation, and creativity. ${ }^{360}$ Thus, in creating an environment that cultivates lawyer well-being, the improved well-being of one or some lawyers will affect positively those around them, thus making teams, departments, and firms more productive and successful.

That healthier employees perform better is critical in the legal profession for several reasons, but notably because of recent client demands for lawyer efficiency. As explained in Section III.B.1 above, firms could avoid addressing lawyer well-being issues on performance-related grounds because their business model was one that thrived on and financially re-

353. Mackey \& Sisodia, supra note 340 , at 86.

354. Achor, Happiness Advantage, supra note 101, at 2-4 (“[H]appiness and optimism fuel performance and achievement.").

355. Huang \& Swedloff, supra note 286, at 337 (citations omitted); AcHor, Happiness Advantage, supra note 101, at 41 ("Data abounds showing that happy workers have higher levels of productivity, produce higher sales, perform better in leadership positions, and receive higher performance ratings and higher pay. They also enjoy more job security and are less likely to take sick days, to quit, or to become burned out.”); Emma Seppälä, The Happiness Track 7-11, 152-61 (2016).

356. Lyubomirsky et al., supra note 338, at 840 (" $[\mathrm{P}]$ ositive affect fosters the following resources, skills, and behaviors: sociability and activity . . ., altruism . . ., liking of self and others ..., strong bodies and immune systems . . ., and effective conflict resolution skills .....").

357. Arnold B. Bakker \& Evangelia Demerouti, Towards a Model of Work Engagement, 13 Career Dev. INT'L 209, 215 (2008). Work engagement is not to be confused with workaholism, as work engagement is positively related to performance, while workaholism is not. Id. at 214 .

358. Achor, Big Potential, supra note 265, at 149.

359. Id. at 148-49; see also id. at 59-86.

360. Id. at 70 . 
warded inefficiency - the billable hour. Over the last few years, however, clients have caused law firms to move away from the traditional hourlybilling model and toward "alternative fee arrangements," or a "mutual agreement between a law firm and [client] for billing and payment of outside legal services that does not rely on straight hourly billing by the firm."361 Such arrangements include fixed price agreements, success fee agreements, contingency pricing, and other alternatives to the traditional billable hour. ${ }^{362}$

The rise of nontraditional billing is "[o]ne of the most potentially significant" changes to the profession in recent years, as it portends the "effective death of the traditional billable hour . . in most law firms." 363 As of 2017, alternative fee arrangements account for $15 \%-20 \%$ of law firm revenues; however, when combined with budget-based pricing, such alternatives to the billable hour "may well account for 80 or 90 percent of all revenues." 364 Nearly $68 \%$ of all firms are working with clients to create alternative fee arrangements, and nearly $77 \%$ of firms with more than 250 lawyers are doing so. ${ }^{365}$

Large companies are seeking to change the billing model for their outside counsel and are insisting on alternative fee arrangements. For instance, Microsoft enacted a "Strategic Partner Program" on July 1, 2017, which "plac[ed] a stronger focus on alternative fee arrangements, retainer payments, diversity and developing relationships with outside counsel that go beyond the billable hour." 366 At that time, approximately $55 \%-60 \%$ of its outside counsel matters were billed on a non-hourly, alternative-fee basis, with the hope of raising that figure to "a very robust 90 percent" by mid-2019. ${ }^{367}$ Additionally, pharmaceutical company GlaxoSmithKline had $80 \%$ of outside legal work in 2017 done through an alternative fee arrangement, compared with just $3 \%$ in $2008 .{ }^{368}$

361. Alm Legal Intelligence, Speaking Different Languages: Alternative Fee Arrangements for Law Firms and Legal Departments 10 (2012).

362. For a list of examples of alternative fee arrangements, see $i d$.

363. Ctr. for the Study of the Legal Profession, Georgetown Law \& Legal Exec. Inst., Thompson Reuters, 2017 Report on the State of the Legal MARKET 9 (2017), https://www.legalexecutiveinstitute.com/wp-content/uploads/ 2017/01/2017-Report-on-the-State-of-the-Legal-Market.pdf [https://perma.cc/ E8QH-ARN2].

364. Id. at 10.

365. Altman Weil, Inc., 2018 Law Firms in Transition: An Altman Weil Flash SurveY 62 (2018), http://www.altmanweil.com//dir_docs/resource/ 45F5B3DD-5889-4BA3-9D05-C8F86CDB8223_document.pdf [https://perma.cc/ 5XPE-WBL3].

366. David Ruiz, Microsoft Deputy GC: In New Outside Counsel Program, AFAs Plus Competition Equals Success, LAw.COM (Aug. 7, 2017), https://www.law.com/2017/ 08/07/microsoft-deputy-gc-in-new-outside-counsel-program-afas-plus-competitionequals-success/ [https://perma.cc/VLK8-59D7].

367. Id.

368. Randall Colburn, How Brennan Torregrossa and GlaxoSmithKline are Moving Beyond the Billable Hour, Modern Counsel (Mar. 15, 2018), https://modern-counsel.com/2018/glaxosmithkline/ [https://perma.cc/DD98-HTHF]. 
Reich: Capitalizing on Healthy Lawyers: The Business Case for Law Firms

In all, since 2008, clients have asserted more control over decisions regarding their legal representation and are "insisting on more value for their legal spend"-i.e., "higher levels of predictability, efficiency, and cost effectiveness in the delivery of legal services, quality being assumed." 369 Moreover, a 2019 survey revealed that $82 \%$ of in-house corporate counsel are seeking to cut their company's legal spend over the next two years. ${ }^{370}$ Thus, since the billable hour model is one that is antithetical to productivity and efficiency ${ }^{371}$ — why finish a task efficiently in four hours when it could billed over six? - clients are now demanding firms move away from this model, and instead will award their business to firms that demonstrate they can perform the work productively, efficiently, predictably, and costeffectively. ${ }^{372}$ Accordingly, firms that prioritize lawyers' well-being will be better equipped to meet client demands for exceptional yet efficient service.

\section{Retention}

As discussed in Section III.A.3 above, mental health and addiction issues can lead to high attrition rates. By contrast, firms that promote lawyer well-being will see improved retention rates. This is borne out by experiences in other industries; for example, conscious businesses typically operate with much lower levels of employee turnover, which avoids the replacement cost of new employee hiring and training. ${ }^{373}$

Moreover, general counsel at major corporations have begun to understand that balance in the lives of their outside lawyers can be an important factor in their companies' bottom line. ${ }^{374}$ In fact, general counsel will consider lawyer attrition as well as the quality-of-life issues that affect

369. 2019 Report on the State of the Legal Market, supra note 167 , at 13.

370. Ernst \& Young, Reimagining the Legal Function Report 2019, at 4, 7-8 (2019), https://www.ey.com/en_gl/tax/why-the-legal-function-must-bereimagined-for-the-digital-age [https://perma.cc/FW3G-P439].

371. HARPER, supra note 20 , at 78 ("Total elapsed time without regard to the quality or usefulness of the result reveals nothing about a worker's value. More hours often mean the opposite of real productivity. No one inside most big firms questions this perversion because leadership's primary goal is increasing equity partner wealth. More is better, and the misnomer 'productivity' persists.")

372. 2019 Report on the State of the Legal Market, supra note 167, at 13.

373. MACKey \& Sisodia, supra note 340 , at 287. For instance, at the conscious business The Container Store, "turnover is less than 10 percent per year, in an industry that's over 100 percent." Id. at 89-90 (internal quotation marks omitted). Additionally, Jet Blue enacted a peer-to-peer recognition program in which one employee could nominate a coworker to be acknowledged for their performance; not only did this program lead to "significantly higher levels of employee performance and engagement," it also led to an increase in retention. ACHOR, BIg PotenTIAL, supra note 265, at 136-37.

374. HARPER, supra note 20, at 174 ("No other company would treat its most important commodity poorly enough to cause a turnover rate of 85 percent for first year lawyers who are gone by the sixth year. Why are you doing it? How can you get away with that?"). 
attrition when making decisions of which outside firms to retain. ${ }^{375}$ These corporate clients recognize "that the absence of balance contributes to high associate attrition rates in large law firms and that attrition, in turn, imposes costs that result from the loss of institutional knowledge and continuity." 376 As the former senior vice president and general counsel of the Association of Corporate Counsel recognized more generally, the "greatest investment in any new lawyer" is in "developing the culture, support mechanisms and leadership initiatives that will ensure [that] lawyer's success," because firms will not only receive the "returns" generated by that lawyer, but the "larger benefits of cultivating a better work environment will rain down on everyone in the firm."377 Indeed, in August 2019, 3Mwhose legal department is itself a signatory to the ABA Wellness Pledgehas incorporated the pledge into its requests for proposals from outside counsel by asking "law firms if they have signed the pledge and what specific action they have taken to promote well-being among the lawyers and other legal professionals in their firm." 378

Thus, firms that make efforts to retain their lawyers will not only avoid turnover costs and lose institutional knowledge about matters and clients as well as client relationships generally, it will help to foster and retain clients in the first place. And firms will be better equipped to retain their lawyers by taking steps to promote and prioritize their wellness and wellbeing.

\section{Recruiting Younger Lawyers: Choices for the New Generations ${ }^{379}$}

The third area in which law firms will benefit will be in recruitment, particularly with respect to millennial and, as they enter the profession, Generation $\mathrm{Z}$ lawyers. ${ }^{380}$ People in these younger generations suffer from "higher levels of depression, anxiety, and suicide ideation than they did a

375. Id. at 189-90; see also id. (quoting one general counsel as saying they look to "retention issues, training, and flex time" when selecting outside counsel, as those issues "are all creeping into the alternative fee discussion").

376. Id. at 174 .

377. Id. at 175 .

378. Kristen Rasmussen, Making Mental Health a Money Matter: $3 M$ Uses ABA Wellness Pledge in Outside Counsel Search, Corp. Couns., https://www.law.com/ corpcounsel/2019/08/25/making-mental-health-a-money-matter-3m-uses-aba-well ness-pledge-in-outside-counsel-search/ [https://perma.cc/WD4E-8QAX].

379. The author notes the anachronism in, and perhaps showing his age by, paraphrasing a corporate slogan from the Generation-X era as a title for a section discussing millennials and Generation $\mathrm{Z}$ lawyers. Pepsi, the Choice of a New Generation, Duke Univ. Digital Repository, Resource of Outdoor Advertising DEscriptions, https://idn.duke.edu/ark:/87924/r3fb4x59j [https://perma.cc/ 5WEL-X2GK] (last visited May 7, 2020).

380. Millennials are those born, roughly, in the 1980s and early 1990s. Corey Seemiller \& Meghan Grace, Generation Z Goes to College 4 (2016). Generation Z "refers to those born between 1995 and 2010." Id. at 6 . 
decade ago."381 Indeed, in 2009, the average age of individuals diagnosed with depression was fourteen and a half, compared to twenty-nine in 1978.382

Younger millennials are now entering the profession, with older millennials having as much as ten years or more in practice. That latter age cohort has increased a spike in mental health issues. A recent study by BlueCross BlueShield revealed that the prevalence of depression among millennials has increased by $31 \%$ from 2014 to 2017 , and is the top condition affecting millennials by adverse health impact. ${ }^{383}$ Depression is $18 \%$ more prevalent for older millennials than Generation X'ers at the same age. 384

The trend is more concerning for the next generation. Generation Z'ers are "on the verge of the most severe mental health crisis for young people in decades." 385 Depression of middle- and high school-aged Generation Z children has "skyrocketed" between 2012 and 2015, a trend that exists across all demographic and socioeconomic classes. ${ }^{386}$ In fact, a 2015 study by the U.S. Department of Health and Human Services found that " $56 \%$ more teens experienced a major depressive episode in 2015 than in 2010, and 60\% more experienced severe impairment." 387

This trend has continued as Generation Z'ers have gotten older. They are increasingly entering college with mental health issues, ${ }^{388}$ with nearly twice the number of incoming students in 2016 indicating they feel depressed than those who entered college in 2009. ${ }^{389}$ They are more likely to report feeling "overwhelming anxiety" and that they feel "so depressed they [can] not function." 390 Additionally, a 2019 study revealed that current twenty to twenty-one-year-olds were $78 \%$ more likely to have experienced serious psychological distress in the last month than twenty to

381. Thomas Curran \& Andrew P. Hill, Perfectionisim Is Increasing over Time: A Meta-Analysis of Birth Cohort Differences from 1989 to 2016, 145 Psychol. Bull. 410, 420 (2019).

382. Achor, Big Potential, supra note 265, at 22.

383. Blue Cross Blue Shield, The Health of America Report: The Health of Millennials 2 (2019), https://www.bcbs.com/sites/default/files/file-attach ments/health-of-america-report/HOA-Millennial_Health_0.pdf [https://perma .cc/WKG7-YFUD]. Substance use and alcohol use disorders were the second and third conditions affecting millennials by adverse health impact. Id.

384. Id. at 3 .

385. Twenge et al., supra note 280 , at 93 .

386. Id. at 102-03; see also id. (observing that "more and more teens [say] they don't enjoy life").

387. Id. at 108; see also Dep't of Health \& Hum. Servs., Subs. Abuse \& Mental Health Servs. Admin., Key Substance Use and Mental Health Indicators in the United States: Results from the 2015 National Survey on Drug Use AND HEALth 38 (2016), https://www.samhsa.gov/data/sites/default/files/ NSDUH-FFR1-2015/NSDUH-FFR1-2015/NSDUH-FFR1-2015.pdf [https://perma .cc/2WZU-H5TL].

388. Seemiller \& Grace, supra note 380, at 196-97.

389. Twenge et al., supra note 280, at 103.

390. Id. 
twenty-one-year-olds in 2008, and current eighteen to twenty-five-year-olds are $71 \%$ more likely to experience such distress than eighteen to twentyfive-year-olds in 2008. ${ }^{391}$ In all, Generation Z'ers are $49 \%$ more likely than millennials to have reported serious psychological distress in the past month. ${ }^{392}$

Perhaps not surprisingly, then, millennials prioritize work-life balance when choosing employment, even more than salary. ${ }^{393}$ As a general matter, millennials seek meaning and purpose in their work, as well as supportive and nurturing work environments. ${ }^{394}$ In fact, a 2016 survey of millennials revealed that, salary excluded, work-life balance is the most important characteristic millennials search for when choosing a job. ${ }^{395}$ Other top considerations include leadership opportunities, a sense of meaning or purpose in their work, training, and the impact the work has on society ${ }^{396}$ - that is, the types of motivations and values that enhance one's subjective well-being and, in turn, inversely correlate to depression. ${ }^{397}$ Thus, millennials respond best to employers who convey "you matter to us"- that is, employers who see their employees' humanity and well-being is integral to the company and its success. ${ }^{398}$

With Generation $\mathrm{Z}$ beginning to enter law school and the profession, firms that address mental health and addiction issues and that foster a

391. Id. at 188 .

392. Id.

393. Joanne G. Sujansky \& Jan Ferri-Reed, Keeping the Millennials: Why Companies Are losing Billions in Turnover to This Generation-and What то Do Aвоuт Iт 5 (2009); see also id. at 11, 51 (citing a study finding that salary was only the fourth-most important "determinant of an attractive workplace," following health benefits, work-life balance, and promotional opportunities); Leslie Larkin Cooney Walking the Legal Tightrope: Solutions for Achieving a Balanced Life in Law, 47 SAn Diego L. Rev. 421, 450 (2010) ("Millennials undoubtedly seek more work-life balance . . . ."); Eddy S.W. Ng et al., New Generation, Great Expectations: A Field of Study of the Millennial Generation, 25 J. Bus. Psychol. 281, 289 (2010) ("The need for work-life balance . . remains an important factor in [millennials'] job choice decisions, despite an expectation for rapid advancement and pay increases."); Katie French, Millennials Prioritising Work-Life Balance over Job Security, Study Finds, TELEGRAPH (UK) (Nov. 19, 2018), https://www.telegraph.co.uk/news/2018/11/19/mil lennials-prioritising-work-life-balance-job-security-applying/ [https://perma.cc/ S7C8-YQDY] (reporting on a survey finding that one third of millennials believe that work-life balance is the "most important factor" in choosing a job).

394. See $\mathrm{Ng}$ et al., supra note 393, at 282-83, 288-89.

395. Deloitte, The 2016 Deloitte Millennial Survey: Winning over the Next Generation of Leaders 20 \& fig.11 (2016), https://www2.deloitte.com/con tent/dam/Deloitte/global/Documents/About-Deloitte/gx-millenial-survey-2016exec-summary.pdf [https://perma.cc/9WTN-MB9V].

396. Id.

397. See supra notes 123-127 and accompanying text; cf. Brafford, supra note 179, at 99-102 (arguing that law firms that promote and foster positive psychology will be "recruiting magnets for law firms").

398. Brafford, supra note 179, at 102 ("The common theme to the Millennial profile is that they respond best to employers that convey 'you matter to us'; your well-being and enthusiasm are important to our success."). 
healthy environment will help attract these incoming interns and associates. They experience mental health issues in greater frequency than millennials, and they are more likely to talk about ${ }^{399}$ and seek help for them. ${ }^{400}$

In fact, law students on the millennial/Generation $\mathrm{Z}$ cusp have made clear that mental health is a priority to them as they enter the legal profession. In its 2019 Summer Associates Survey, The American Lawyer reported that $42 \%$ of respondents said they are concerned about their mental health, including because of the "structure of the legal industry." 401 Further, when asked to list their top three factors in considering an employment offer from a law firm, work-life balance was the most important factor among the respondents. ${ }^{402}$

This prioritization of mental health and work-life balance is not an anomaly in this one survey, as young millennial and Generation $\mathrm{Z}$ students are engaging in activism to promote and mental health in the profession. For instance, in 2019 the Virginia State Bar removed questions relating to mental health history and treatment in response to a student-led movement for it to do so, ${ }^{403}$ and several well-being-related programs at law schools are led by students. ${ }^{404}$ Younger Generation Z students are also campaigning for greater mental health awareness and treatment; for instance, in June 2019, in response to student activism, Oregon enacted a law that will allow students to take "mental health days" from school as an excused absence, just as they would a sick day ${ }^{405}$ Thus, as they enter the workforce, these students certainly will prioritize their mental health and well-being in choosing among employers. ${ }^{406}$

399. Sue Shellenbarger, The Most Anxious Generation Goes to Work, Wall St. J. (May 9, 2019, 12:22 PM), https://www.wsj.com/articles/the-most-anxious-genera tion-goes-to-work-11557418951 [https://perma.cc/QX5C-X6UP].

400. See Am. Psychol. Ass'n, Stress in America: Generation Z 4 (2018), https://www.apa.org/news/press/releases/stress/2018/stress-gen-z.pdf [https:// perma.cc/6F36-N7EN].

401. Dylan Jackson, The 2019 Summer Associates Survey: Wined, Dined and Worried, Am. LAw. (Sept. 23, 2019), https://www.law.com/2019/09/23/the-2019-summer-associates-survey-wined-dined-and-worried/ [https://perma.cc/Y6LH-5D7H].

402. Id.

403. Mattingly, supra note 307.

404. See Jordana Alter Confino, Where Are We on the Road to Law Student WellBeing?: Report on the ABA CoLAP Law Student Assistance Committee Law School Wellness Survey, 68 J. Legal Educ. 650, 693-98 (2020); Karen Sloan, 'Law School Was Kind of a Shock:' Students Take the Lead in Mental Health Initiatives, LAw.com (Aug. 5, 2019), https:/ / www.law.com/2019/08/05/law-school-was-kind-of-a-shock-students-takethe-lead-with-mental-health-initiatives/ [https://perma.cc/6Z45-VGV3].

405. Sarah Zimmerman, Teen Activists Score Mental Health Days for Oregon Students, Associated Press (July 21, 2019), https://apnews.com/b2ce8f6a019846 f7844f59af449ad567 [https://perma.cc/W7EM-JB5Z].

406. Human resources software company Zenefits found that "Gen Z-ers recognize that mental health in the workplace is important, and they are demanding benefits and workplace policies that acknowledge this reality." Nicole Roder, Young Workers Demand Emphasis on Mental Health in the Workplace, ZenefiTs (Jan. 3, 
Consequently, firms that prioritize lawyer health and well-being will be attractive both to lateral lawyers who seek better balance as well as to younger and future lawyers who prioritize their own well-being.

\section{ConClusion}

The legal profession has known for decades that its members suffer from mental illness and addiction in staggering numbers, and firms largely have been unmoved by the moral case for change. As the practice of law has become more of a business, firms can and will make changes to reduce costs, increase efficiencies, and improve profit margins. This Article argues not only that the profession should and should want to create a "better future for our lawyers" 407 by making such changes, but that it is in its interest to do so. Since firms have not wanted to make changes on moral grounds, they can and should at least make them on business ones, and lawyers and the profession itself will benefit as a result. Put differently, why firms make these changes is not as important so long as they are made, and if it takes a cost-benefit analysis for firms and the profession to prioritize lawyer well-being, so be it.

2019), https://www.zenefits.com/blog/young-workers-demand-emphasis-onmental-health-in-the-workplace/ [https://perma.cc/RPA9-A84T].

407. The Path to Lawyer Well-Being, supra note 15, at 47. 